\title{
An efficient representation of glacier dynamics in a semi-distributed hydrological model to bridge glacier and river catchment scales
}

\author{
Michel Wortmann ${ }^{\mathrm{a}, \mathrm{b}, *}$, Tobias Bolch ${ }^{\mathrm{c}, \mathrm{d}}, \mathrm{Su}_{\mathrm{Buda}}^{\mathrm{e}}$, Valentina Krysanova $^{\mathrm{a}}$ \\ ${ }^{a}$ Potsdam Institute for Climate Impact Research, Telegraphenberg A31, 14473 Potsdam, Germany \\ ${ }^{b}$ Department of Geography, University College London, Gower Street, London WC1E 6BT, United Kingdom \\ ${ }^{c}$ Department of Geography, University of Zurich, Winterthurer Strasse 190, 8057 Zuerich, Switzerland \\ ${ }^{d}$ Institute for Cartography, Technische Universität Dresden, 01069 Dresden, Germany \\ ${ }^{e}$ National Climate Centre, Chinese Meteorological Administration, No. 46, Zhongguancun South Street, Beijing, China
}

\begin{abstract}
Glacierised river catchments have been shown to be highly sensitive to climate change, while large populations depend on the water resources originating from them. Hydrological models are used to aid water resource management, yet their treatment of glacier processes is either rudimentary in large-scale applications or linked to fully distributed glacier models that prevent larger model domains. Also, data scarcity in mountainous catchments has hampered the implementation of physically based approaches over entire river catchments. A fully integrated glacier dynamics module was developed for the hydrological model SWIM (SWIM-G) that takes full account of the spatial heterogeneity of mountainous catchments but keeps in line with the semi-distributed disaggregation of the hydrological model. The glacierised part of the catchment is disaggregated into glaciological response units that are based on subbasin, elevation zone and aspect classes. They seamlessly integrate into the hydrological response units of the hydrological model. Robust and simple approaches to ice flow, avalanching, snow accumulation and metamorphism as well as glacier ablation under consideration of aspect, debris cover and sublimation are implemented in the model, balancing process complexity and data availability. The fully integrated model is also capable of simulating a range of other hydrological processes that are common for larger mountainous catchments such as reservoirs, irrigation agriculture and runoff from a diverse soil and vegetation cover. SWIM-G is initialised and calibrated to initial glacier hypsometry, glacier mass balance and river discharge. While the model is intended to be used in medium to large river basins with data-scarce and glacierised headwaters, it is here validated in the data-scarce catchment of the Upper Aksu River, Kyrgyzstan/NW China and in the relatively data-abundant catchment of the Upper Rhone River, Switzerland.
\end{abstract}

Keywords: glaciohydrological model, SWIM, Aksu basin, Rhone basin, glacier mass balance modelling

\footnotetext{
* Corresponding author

Email address: wortmann@pik-potsdam.de (Michel Wortmann)
} 


\section{Introduction}

Hydrological modelling and hydrological climate change impact assessments of mountainous and glacierised catchments are plagued with complications and uncertainties (Klemeš, 1990; Schaefli, 2005; Pellicciotti et al. 2012; Kraaijenbrink et al., 2017). Spatially strongly heterogeneous water balance components such as glaciers, orographic precipitation and permafrost are paired with low observation densities, often resulting in severe data scarcity for hydrological modelling. Glaciers have been of particular concern, as their evolution under a changing climate may have significant consequences for downstream water resources (Huss et al., 2008 Immerzeel et al., 2010; Bolch et al., 2012). Representing long-term glacier dynamics in a general-purpose hydrological catchment model has so far been limited (Naz et al., 2014).

Water management of glacierised catchments relies on hydrological models that estimate the glacier meltwater contribution to river discharge of a given glacier cover, often referred to as glacio-hydrological models. Data gaps are overcome by spatial interpolation and integration as well as empirical parametrisations. There is a range of conceptual, semi-distributed models with a long history that incorporate glacier melt successfully and are mainly based on the Degree-Day approach (Quick and Pipes, 1977; Schaefli et al., 2005 ; Hagg et al., 2007; Duethmann et al., 2013; Hock, 2005). They perform well over 1-10 year time scales, while being parametrised and calibrated to specific mountainous catchments. There are also some fully distributed and often more physically based models with resolutions of 25-300 m (Finger et al., 2011; Immerzeel et al. 2014; Huss et al., 2010b; Dickerson-Lange and Mitchell, 2014). They are spatially more explicit with more parameter redundancy and higher computational demands. Processes are implemented with more physical meaning, such as the full energy balance at the glacier surface for mass balance accounting. This class of models, however, suffers most from data scarcity, often leading to worse validation results than the former, due to the reliance on driving data (e.g. radiation, albedo etc.) that is not easily interpolated to the model domain.

In addition to glacier mass balance modelling, only a few hydrological models consider ice dynamics, i.e. the lateral redistribution of ice down-slope under the force of gravity. For example, the fully distributed GERM model updates glacier cover annually using an empirical parametrisation of ice thickness changes (Huss et al., 2010b). Some two-dimensional glacier models (without catchment hydrology) have been developed to simulate glacier mass balances and ice dynamics from the glacier to the regional scale (Vieli, 2015; Clarke et al., 2015; Rowan et al., 2015). Fully integrated glacio-hydrological catchment models with a physical description of ice dynamics, however, are rare with the pioneering exception by Naz et al. (2014). They used the shallow ice approximation to evolve glacier surfaces in response to a full energy balance mass balance model and a comprehensive hydrological model at a resolution of $300 \mathrm{~m}$, albeit a catchment size of 
only $422 \mathrm{~km}^{2}$. Few semi-distributed, conceptual models consider ice dynamics as part of the glacier modelling; instead glaciers are only represented as fractional coverage of elevation bands, neglecting the complex terrain in their mass balance and ice flow calculations (e.g. Uhlmann et al., 2013).

Short-comings of current glacio-hydrological models for long-term climate change impact assessments can be loosely divided into problems of a) integration and b) scale:

Integration. Most existing glacio-hydrological models have no or only a simple representation of the remaining catchment hydrology, as it remains a less important factor in small, highly glacierised catchments. However, there is often a considerable distance between the glacierised part of a catchment and the locations where water becomes a socioeconomic and ecological resource. It is in these locations where long-term hydrological observations are recorded that are needed for model calibration. The distance from the glaciers increases the catchment size, increasing the need for more accurate descriptions of the diverse landscape hydrology (e.g. vegetation, groundwater, irrigation agriculture and reservoirs). This is particularly important in long-term studies with drastic glacier changes: Glacier shrinkage exposes more area to solely hydrological processes, while precipitation increase promotes glacier growth but also more runoff in lower-laying areas of the catchment. Similarly, loosely coupled approaches often simulate glacier mass balances and snow cover separately, leading to inconsistencies in the modelling chain (Jost et al., 2012).

Scale. Only fully integrated and mostly physically based models have been used to model both glacier evolution and catchment hydrology. Besides their high demand for driving data, they are constrained to relatively small catchments (a few 10s to a few 1000s of square kilometre in size). This is mainly due to their fully distributed nature and the related grid discretisation. In most cases, these models include a computationally intensive, two-dimensional finite-difference approach to ice flow, for which model runtimes increase drastically with finer resolutions, larger catchments and more sophisticated numerical solutions. The grid resolution is dictated by the complex terrain or the smallest glacier area that is intended to be represented, which puts the maximum grid size to several 100s of meters (Immerzeel et al. (2014) used 500m as the largest found in the literature). While higher resolutions are necessary for the representation of glacier processes, they are unnecessary for hydrological processes in large catchments with sparse observation data.

For long-term assessments of large (partially) glacierised catchments and full mountain ranges, an efficient model is required that integrates a complete description of the catchment hydrology with glacier mass balance and ice dynamics modelling (Naz et al., 2014).

The aim of this study is to propose a glacier dynamics module for a semi-distributed hydrological model with an alternative spatial representation of glaciers based on adaptive units. An extension of the Soil and Water Integrated Model (SWIM, Krysanova et al., 1998) is presented that combines this representation with established and mainly empirical equations describing glacier dynamics and mass balance processes. In- 
tended for long-term and integrated climate change impact assessments, the extended model (subsequently called SWIM-G) enables the simulation of individual glaciers over large and data-scarce catchments in a computationally efficient manner. It is here validated in the data-scarce Upper Aksu catchment, Kyrgyzstan/NW China as well as the relatively data-abundant Upper Rhone catchment, Switzerland. The model bridges the divide between distributed small-scale glacio-hydrological models and large-scale hydrological models that ignore or strongly simplify ice dynamics and individual glaciers.

\section{Methods}

The model integration presented here is based on the idea that proven concepts in hydrological modelling exist (Peel and Blöschl, 2011), while glaciological models are highly specialised and not readily transferable to the catchment scale. Recent advances in glaciological modelling and the emergence of accurate, catchment and region-wide glacier outlines and mass balances (e.g. Fischer et al. $(2014,2015)$ for Switzerland, Pieczonka and Bolch (2015) for the Central Tien Shan) enable catchment-wide modelling on the glacier scale. In the following, the hydrological model SWIM is briefly outlined followed by more detailed descriptions of the newly implemented glacier processes. The calibration and validation strategy is described at the end of this section.

\subsection{The Soil and Water Integrated Model (SWIM)}

The Soil and Water Integrated Model (SWIM) is a semi-distributed, process-based, ecohydrological model (Krysanova et al., 1998) and is a fork of the widely-used model SWAT (Arnold et al., 1993). It was initially developed for long-term climate change impact assessments for medium to large river basins, but has since been developed into a fully integrated ecohydrological model encompassing a number of hydrological and water management processes for both water availability and water quality assessments (Hattermann et al. 2011; Huang et al., 2010; Liersch et al., 2012; Koch et al., 2013). Krysanova et al. (2015) provides an overview of the hydrological processes considered and recent advances in its development.

An extended degree-day method is used to simulate snow melt (Huang et al., 2013a b). It includes a continuous description of ice and water content in the snowpack as well as refreezing, sublimation and metamorphism according to the approach of Gelfan et al. (2004). As it relies on accurate mean daily temperature, $100 \mathrm{~m}$ elevation bands are used to split hydrotopes and to adjust the subbasin mean temperature to the hydrotope elevation by a lapse rate that is catchment specific. The lapse rate varies between $0.3^{\circ} \mathrm{C} / 100 \mathrm{~m}$ for humid condition and up to $0.9^{\circ} \mathrm{C} / 100 \mathrm{~m}$ for dry conditions. Precipitation falls as snow if mean temperature falls below a threshold $T_{s}$ and melts if it exceeds a threshold $T_{m}$ via the degree-day method (Hock and Holmgren, 2005). Both thresholds are subject to calibration but are generally well-confined to $\pm 3{ }^{\circ} \mathrm{C}$. The 
snow module of SWIM provides the main input to the newly developed glacier module, which is described in the following sections.

Four purely hydrological parameters are used in the calibration from the standard SWIM implementation: The evaporation correction factor $E_{c}$ adjusts the potential evaporation derived using the Priestley-Taylor approach (Priestley and Taylor, 1972). The saturated conductivity correction factor $S_{c}$ universally adjusts the conductivity of all soils that is estimated from the particle size distribution. The routing coefficients $R_{2}, R_{4}$ are part of the modified Muskingum channel routing method and are applied to the surface and subsurface flow components, respectively (Krysanova et al., 2005; Krysanova and Wechsung, 2000; Gill, 1978).

\subsection{Spatial disaggregation of glaciers}

SWIM is a semi-distributed, hydrological model with three levels of disaggregation: the basin, subbasins and the hydrotopes (or Hydrological Response Units, HRU). The hydrotopes subdivide the subbasins typically by unique combinations of land cover, soil class and elevation band, but this can be refined by other variables. They provide an adaptive spatial unit depending on the process scale and available data. Taking on this proven hydrological concept, they were here used to represent glaciers. The hydrotopes were used to model the complex mountainous terrain that determines glacier geometry and distribution by considering slope and aspect classes as well as elevation zones. This type of terrain abstraction is common in geomorphology with established threshold values and classification methods (Bishop et al., 2003; Cronin, 2000 Rasemann et al., 2004), while it was here used with the focus on glacier properties.

In the potential glacier region of the river basin, the hydrotopes are unique combinations of three terrain classifications that were derived from the Digital Elevation Model (DEM): a) a valley and hillslope class (using a slope threshold), b) elevation zones with small intervals in valleys and larger intervals on hillslopes, and $c$ ) four, regularly spaced aspect classes on hillslopes only. The unique combinations produce a noisy map that needs to be aggregated to a minimum area threshold (Figure 1). The aggregation was achieved through a successive remove and neighbourhood filling routine. That is, first all areas below a defined minimum threshold were removed and the voids were then filled by growing the neighbouring units. This was done for each subbasin individually, so that subbasin boundaries remain intact. The aggregation and suitable thresholds are important for the creation of similarly sized units, preventing numerical issues when routing ice between irregular units (Sanzana et al., 2013; Marshall and Clarke, 1999).

Typical elevation zones in hydrological models vary between 20-200 m (Lindström et al., 1997). The variable elevation zone intervals in valleys and hillslopes stems from the desire to have equally sized spatial units. Typical slope angles for the two classes should thus govern the choice of intervals. A factor of 10 
between valley and hillslope intervals, for example, will lead to equal downslope distances with typical slope angles of $3.9^{\circ}$ and $34^{\circ}$. Distinguishing between slope aspect is important to subdivide elevation zones. The aspect classes break these into distinct hillslope units that are more representative of glacial hillslopes than an entire elevation zone and distinguish glaciers with different exposure. The minimum area threshold limits the model to glaciers larger than this threshold, although fractional coverages are possible as a glacier retreats or with avalanche prone areas. These representative units resolve the glacial systems of the catchment as well as the hillslopes contributing to glacier accumulation.

The slope threshold, the elevation intervals, the number of aspect classes and the minimum area of aggregation are threshold values that were adapted to the desired level of terrain discretisation. A slope threshold of $<15^{\circ}$, elevation zones of $40 \mathrm{~m}(20 \mathrm{~m})$ in valleys and $400 \mathrm{~m}(200 \mathrm{~m})$ on hillslopes, four aspect classes and a minimum area of $0.5 \mathrm{~km}^{2}\left(0.1 \mathrm{~km}^{2}\right)$ were used in the Upper Aksu (Upper Rhone) catchment. These values produced 12980 (12179) glacier units with an average area of $0.95 \mathrm{~km}^{2}\left(0.33 \mathrm{~km}^{2}\right)$ and maximum area of $3.48 \mathrm{~km}^{2}\left(2.30 \mathrm{~km}^{2}\right)$.

The numerical stability of varying glacier unit sizes was tested by two additional model setups of the Upper Rhone catchment with roughly half and double the number of units as described in the Supplementary Material (Section S3). Results are largely stable and differences are within the calibration uncertainty. Area loss was slightly stronger as the number of units is decreased (by $0.06 \% \mathrm{a}^{-1}$ ), possibly due a greater reliance on the fractional glacier area with increasing unit sizes.

Other spatial attributes relevant to the hydrological model were mapped onto the spatial structure of the glacier units, i.e. for each hydrotope the dominant land cover and soil class was used. Soil inventories in mountainous areas mainly apply to valleys (alluvial fans, plateaus), while the hillslopes are mainly composed of bare rock and extremely shallow soils. As a consequence, the soil depth on the hillslope units was reduced to $300 \mathrm{~mm}$ in line with typical soil depths in steep terrain (Dietrich et al., 1995; Heimsath et al., 1999), essentially a thin layer of gravel behaving close to impervious rock. All hillslopes are given the land cover category bare soil, i.e. the soil cover is treated as loosely consolidated, unvegetated soil that describes the loose gravel and small alluvial fans of high mountain terrain.

\subsection{Glacier formation and accumulation}

All snow processes are governed by the existing snow module, including a description of the ice and water content of the snowpack calculating melt accordingly (Section 2.1). If at the end of the ablation season (defined as 90 days after the summer solstice, i.e. end of September in the northern hemisphere) snow or firn is left in the hydrotope and the snowpack (in water equivalent) exceeds a critical height $H_{c}$ [mw.e.], it turns into glacial ice and is subject to ice flow. $H_{c}$ is dependent on both slope $\alpha$ and shear stress $\tau_{s}$, the 
force the ice needs to overcome to deform under its own weight. Although this varies between glaciers and regions, a global average of $100 \mathrm{kPa}$ is widely accepted (Cuffey and Paterson, 2010; Dudeja, 2011; Linsbauer et al., 2012). This physical relationship between slope and glacier thickness in water equivalents is described by (Cuffey and Paterson, 2010):

$$
H_{c}=\frac{\tau_{s}}{1000 \cdot g \cdot \tan (\alpha)}
$$

with gravity $g\left(9.8066 \mathrm{~m} \mathrm{~s}^{-2}\right)$ and slope angle $\alpha\left[^{\circ}\right]$ with a minimum of $0.01^{\circ}$. The sensitivity of the shear stress assumption is shown in Supplementary Material (Section S2.3). The glacier module is only active and perennial snow becomes part of the glacier if down-slope mass redistribution is viable through ice creep and slip or avalanching; that is, if the snowpack plus already existing ice exceeds $H_{c}$. The snow module is simulating all snow processes including firn not covering glaciers and snow on glaciers over the melt season.

We fully acknowledge that shear stress deviates locally and between glaciers from the global mean. Cuffey and Paterson (2010) give a typical range of 50-200 kPa. Since actual observed estimate depend on ice thickness measurements, the average value remains the best estimate for the majority of glaciers. Attempts to spatially distribute this estimate for single glaciers (e.g. using empirical functions, see Haeberli and Hoelzle, 1995), rely on flow lines and two DEMs. These are not readily available for the majority of glaciers and if so, are mostly only available for the large valley glaciers.

\subsection{Ice flow}

The routing between the glacier units is processed similarly to the subbasin routing, i.e. according to the flow direction given by the DEM. Ice flow occurs if the critical height $H_{c}$ is exceeded; if the thickness decreases below $H_{c}$, the ice area of the unit is proportionally decreased to simulate a slow terminus recession. Figure 2 shows the routing between the glacier units in a single subbasin and a valley cross-section of three units. The flow volume $Q_{i}\left[\mathrm{~m}^{3}\right.$ w.e. $\left.\mathrm{a}^{-1}\right]$ is based on Glen's Flow Law and the semi-empirical adaptation suggested by Marshall et al. (2011):

$$
Q_{i}=\chi \cdot A_{u} \cdot H^{5} \cdot \tan (\alpha)^{3}
$$

with area of the glacier unit $A_{u}\left[\mathrm{~m}^{2}\right]$, glacier thickness $H$ [m w.e.], slope $\alpha\left[^{\circ}\right]\left(\min .0 .01^{\circ}\right.$ ) and the rheology term $\chi\left[\mathrm{m}^{-4} \mathrm{a}^{-1}\right]$ that is subject to calibration. The flux $Q_{i}$ is routed to the next glacier unit, but is constrained to the volume above the critical height. This constraint is needed to prevent glaciers from eroding indefinitely.

Independent thickness measurements or simulations may be used to calibrate the rheology term $\chi$. We used GlabTop2 simulations for both catchments. The GlabTop approach uses an empirical relation between average shear stress and elevation range of individual glaciers and is calibrated with geometric information 
from paleoglaciers and radio echo soundings on contemporary glaciers (Linsbauer et al., 2012 ; Frey et al. 2014). The average vertical error was shown to be 7-25\% (Frey et al., 2014), which is comparatively small given the uncertainties of the catchment-wide uniform shear stress assumption in our model. The sensitivity of $\chi$ on ice volume and a comparison with the GlabTop2 simulations is given in the Supplementary Material $(\mathrm{S} 2.4)$.

To account for more accurate glacier area changes that in turn have a strong impact on catchment wide glacier melt, the glacier critical height is maintained if melting occurs and the fraction of glacier area is reduced instead (as illustrated in Figure $2 \mathrm{~b}$ ). This simulates the gradual recession of a glacier front up-slope, exposing a decreasing area to melting after the glacier falls below the critical height. An approximation of the frontal melt area is necessary, however, to adequately account for melt of the receding glacier unit. Since the glacier units have irregular shapes, width and length may be approximated by $\sqrt{A_{u}}$, assuming the average shape to be close to a square. Where the length is overestimated (e.g. in steep and wide valleys), the width is underestimated and vice versa. We are assuming a wedge-shaped glacier front with a constant height equal to $H_{c}$ and a length $l$ proportional to the changing volume below the critical height, as described by:

$$
l=\sqrt{A_{u}} \cdot \frac{H}{H_{c}}
$$

The melt area $A_{m}\left[\mathrm{~km}^{2}\right]$ is thus:

$$
A_{m}=\sqrt{A_{u}} \cdot \sqrt{l^{2}+H_{c}^{2}}
$$

This subgrid treatment of glacier area allows for a more accurate sensitivity to temperature than keeping the glacier area constant until ice thickness reaches 0 in the glacier unit.

Observed elevations (i.e. the SRTM-3 DEM at 90m spatial resolution) were used to vertically distribute melt temperatures, rather than relying on modelled bed elevations and using the evolving glacier surface elevation. This eliminates the dependency on more complex thickness simulations (e.g. GlabTop2) that are only used where available to calibrate the rheology parameter $\chi$. This simplification is warranted because the simulated ice thickness does not decrease below the critical hight, limiting the thickness variations. Impacts on glacier area and mass changes were found to be small (as shown in the Supplementary Material, Section $\mathrm{S} 4)$.

\subsection{Avalanching}

Avalanching represents a more rapid form of snow and ice redistribution as the majority of the snow or firn column is removed and transported down-slope. The avalanche-prone areas are identified by a simple slope threshold that is physically based and well constrained to a range of $35-45^{\circ}$ (Schweizer et al., 2003) and 
should be adapted to the observed glacier hypsometry and distribution. If the snow and glacier thickness exceed the critical height, the snow is accumulated on the remaining fraction of the glacier unit or if the avalanche proportion is greater than $90 \%$, all snow is transported down-slope to the next glacier unit. This upper threshold is needed for numerical stability to avoid large snow masses 'piling up' on small fractions of the glacier unit. Although we found the impact of avalanching on catchment-wide discharge simulations to be insignificant, the process is needed to account for glacier area variations above the Equilibrium Line Altitude (ELA) that are present in observed glacier outlines. Excluding it would lead to even very steep slopes - common for elevations above the ELA - to be ice covered and in turn would erroneously increase the total glacier area.

\subsection{Glacier melt}

The well-tested Degree-Day approach was implemented to simulate glacier melt, as temperature is the 'least uncertain' available climate variable (Hock, 2003). Glacier meltwater is collected in a linear reservoir together with liquid precipitation over the glacier and released as glacier discharge $Q_{g}$ with a delay described by the residence time. This reservoir simulates the water storage capacity of glaciers and the observed delay of glacier discharge after intensive melting periods (Cuffey and Paterson, 2010; Jansson et al., 2003). The following equations describe the glacier melt $M_{g}$ and water outflow $Q_{w}$ from the linear reservoir $V_{w}$ :

$$
M_{g}= \begin{cases}\delta_{g} \cdot T & \text { if } T>T_{m} \text { and } H_{s}=0 \\ 0 & \text { otherwise }\end{cases}
$$

with the Degree-Day factor $\delta_{g}\left[\mathrm{~mm}^{\circ} \mathrm{C}^{-1} \mathrm{~d}^{-1}\right]$, daily mean temperature $T\left[{ }^{\circ} \mathrm{C}\right]$ and melt threshold temperature $T_{m}\left[{ }^{\circ} \mathrm{C}\right]$ and snow height $H_{s}$.

$$
\frac{\Delta V_{w}}{d}=M_{g}+P_{l}-Q_{w}
$$

$$
Q_{w}=\frac{V_{w}}{t_{r}}
$$

with liquid precipitation $P_{l}$ and residence time $t_{r}$ [d]. The latter ranges between 1-10 days and may be calibrated, for example, using individual melt events without rain. The glacier water outflow is then subject to the same infiltration and surface runoff processes as liquid precipitation. The soft glacier bed is described by a shallow, highly permeable soil, which saturates quickly resulting in high rates of surface runoff throughout the melt season. We have neglected the effects of an evolving subglacial channel network because it has little impact on catchments larger than a single glacier group and with significant contributions of precipitation to discharge, especially at daily time steps (Hock and Hooke, 1993; Cuffey and Paterson, 2010). Including 
the process would have lead to additional parameter redundancy.

Two processes were considered that alter the melt rate over space and time: a) slope aspect and terrain shading (Section 2.8) and b) supraglacial debris cover (Section 2.9). Both processes have been shown to have a significant influence on glacier melt and in turn the spatial distribution of glaciers over longer time periods. Although their governing processes are highly complex, two simple approaches are used to approximate their effects and to spatially distribute Degree-Day melting rates. It should be noted that, as a consequence, the Degree-Day factor $\delta_{g}$ as used in Equation (5) is a pure melt factor on clean ice. Aspect, terrain shading and supraglacial debris influence its value, while sublimation also contributes to ablation. When comparing Degree-Day factors reported in the literature, this needs to be considered, i.e. factors computed from ablation stakes are likely to be slightly higher depending on the rates of sublimation and on the surface exposure.

\subsection{Sublimation}

In most glacierised regions sublimation from the glacier is considered a negligible factor, with rates often far below the error of accumulation rates (Hock and Holmgren, 2005; Gascoin et al., 2011). This is mainly due to the fact that sublimation consumes 8.5 times as much energy than melting (latent heat of sublimation: $2.838 \times 10^{6} \mathrm{~J} \mathrm{~kg}^{-1}$ versus latent heat of fusion: $\left.0.334 \times 10^{6} \mathrm{~J} \mathrm{~kg}^{-1}\right)$. In dry and high elevation zones, however, the proportion of energy consumed by sublimation rises to significant levels, suppressing melt rates and meltwater runoff as a result (Zhang et al., 2006; Mölg et al., 2009). High wind speeds and large vapour pressure deficits (or low relative humidity) favour sublimation.

Modelling day-to-day variations in sublimation rates is only possible with a full energy balance model. However, approximate average ratios of energy used for sublimation in the annual mass balance allow the coupling of sublimation with melting and consider the process at least on annual timescales (Kaser, 2001). Assuming ablation is made up of sublimation $S$ and melting $M_{g}$, the energy balance with a positive sublimation ratio $\Gamma$ can be described as follows:

$$
S=\xi \cdot \frac{\Gamma}{L_{s}} ; \quad 0<\Gamma<1
$$

$$
M_{g}=\xi \cdot \frac{1-\Gamma}{L_{f}}
$$

with the total available energy $\xi\left[\mathrm{J} \mathrm{kg}^{-1}\right]$ and the latent heat of fusion $L_{f}\left[\mathrm{~J} \mathrm{~kg}^{-1}\right]$ and of sublimation $L_{s}\left[\mathrm{~J} \mathrm{~kg}^{-1}\right]$. Using the Degree-Day approach from Equation (5), $M_{g}$ can be replaced to solve for $\xi$ as follows:

$$
\xi=\delta_{g} \cdot T_{+} \cdot \frac{L_{f}}{1-\Gamma}
$$


Using Equation (8), sublimation can be described by:

$$
S=\delta_{g} \cdot T_{+} \cdot \frac{\Gamma \cdot L_{f}}{(1-\Gamma) \cdot L_{s}}
$$

This allows to include sublimation from glaciers using the proven Degree-Day factor approach while only adding a single parameter that can be estimated from general climatic conditions and sparse energy balance studies. Low observed or calibrated Degree-Day factors are an indication for high proportions of energy used for sublimation (Zhang et al., 2006; Winkler et al., 2009). We recognise that the fraction of energy used may vary significantly at the daily timescale, yet it is implemented at that timescale due to its simultaneous calculation with melt and is aggregated to annual sums.

\subsection{Slope aspect and terrain shading}

Slope aspect and terrain shading alter the amount of short-wave solar radiation a glacier area receives, which is the dominant driver of glacier melt (Paul, 2010). A first order approximation of this variability is given by the potential sunshine duration per day a slope receives ignoring clouds, a variable readily inferable from a DEM. The slightly greater accuracy of using the clear-sky solar radiation did not warrant the additional calibration parameter that the use in the model requires (e.g. the radiation factor in Pellicciotti et al., 2005 or the radiation coefficient in Huss et al., 2008). Hours of sunlight were computed for both the summer $h_{s}$ and winter $h_{w}$ solstice and interpolated for all days in between with a sine curve. The HBV-ETH model uses a similar sinusoidal differentiation of the Degree-Day factor, but with empirical boundaries (Hock and Holmgren, 2005). The basin-wide Degree-Day factor $\delta_{g}$ is localised by linear scaling as $\delta_{i}$ :

$$
h_{i}=h_{w}+\frac{h_{s}-h_{w}}{2} \cdot\left(1+\cos \frac{2 \pi \cdot i}{365}\right)
$$

$$
\delta_{i}=\delta_{g} \cdot \frac{h_{i}}{12}
$$

where $i$ are the days since the summer solstice, sun hours on day $i$, on the summer and winter solstice are $h_{i}, h_{s}, h_{w}$ (12 signifying the potential hours at the equinox on an unshaded horizontal surface). Although potential sun hours neglect cloud shadowing and the fact that melting is also driven by turbulent heat flux and diffuse radiation, it provides an efficient method to vary the melt rate over complex terrain without introducing additional parameters. The Degree-Day approach enables the calibration of other melt terms implicitly. 


\subsection{Debris cover}

A supraglacial debris cover has long been shown to first increase glacier ablation up to a thickness of a few centimetres and then significantly decrease ablation (Östrem, 1959; Bozhinskiy et al., 1986; Nicholson and Benn, 2006). The initial increase in melting is caused by the decreased albedo of thin debris or aerosol deposition and enhanced thermal conductivity to the glacier ice. This effect, however, is rapidly decreased by the thermal shielding effect of debris layers thicker than a few centimetres. Observing the initial increase has been difficult and including the effect in modelling would require estimating debris thickness with errors smaller then the threshold thickness. Since this is beyond the precision of the model, only the decreasing effect of such a debris layer is considered here.

Several in-situ studies have linked debris cover to subdebris ablation rates using a negative exponential relationship based on the pioneering work by Östrem (1959) (Mattson, 1993; Nicholson and Benn, 2006, e.g. in the Himalaya and several other regions). Considering the measured daily mean temperature, the ablation can be expressed in terms of Degree-Day factors. The simplified Østrem curve without the initial increase is described by the following empirical equation:

$$
\delta_{d}=\delta_{i} \cdot e^{-\gamma \cdot H_{d}}
$$

with the clean ice melt factor $\delta_{i}\left[\mathrm{~mm}^{\circ} \mathrm{C}^{-1} \mathrm{~d}^{-1}\right]$, the debris thickness $H_{d}[\mathrm{~cm}]$ and the slope factor $\gamma$. Although the latter parameter varies between studies and glaciers, it tends to be similar, while the clean ice melt factor varies more.

Observations of subdebris ablation are sparse, so that mean values for the slope factor must be used in most cases. For our study, findings from the largest glacier of the Tien Shan, the heavily debris-covered South Inylchek glacier, Kyrgyzstan (located in the Upper Aksu catchment) by Hagg et al. (2008) were used. They found a value of $\gamma=0.0572$ that is able to describe their ablation observations with a correlation of 0.94. Juen et al. (2014) report similar findings from the Koxkar glacier (also in the Upper Aksu catchment). Specific values for the the Upper Rhone catchment are absent, since debris-covered glaciers are rare.

As delineating the spatial distribution and estimating the thickness of debris cover over an entire river catchment is near to impossible, let alone knowing its development in the future, a dynamical approximation of the glacier cover was implemented. Supraglacial debris has several origins: deposition of colluvial material from rock avalanches and landslides, emergence of subglacial moraines and melt out of englacial debris are the main processes involved (Bolch, 2011). While the first two processes are local and glacier specific, englacial debris melt out is the only one mainly driven by meteorology and universally applicable to a wider region (with varying intensity between regions). To simulate the evolution of debris produced by this process, a 
physically-based approach describing the englacial debris concentration as shown by Bozhinskiy et al. (1986) in a more complex form was implemented. While snow accumulation decreases the concentration, melting increases it and ice flow 'dilutes' the downstream concentration with the one upstream.

An assumed initial debris concentration $C_{0}$ (dimensionless) is altered by melting and accumulation in a glacier unit with the specific debris concentration $C_{g}$ over the daily time step $d$ according to the following equation:

$$
\frac{\Delta C_{g}}{d}=C_{g} \cdot \frac{A-H_{s}}{H_{g}}+\left(C_{u}-C_{g}\right) \cdot \frac{H_{q}}{H_{g}} ; \quad C_{0} \leq C_{g}<1
$$

with glacier thickness $H_{g}$, glacier ablation $A$ (melt and sublimation), firn accumulation $H_{s}$, ice flux height $H_{q}$ and debris concentration of the upstream unit $C_{u}$. The first term changes the concentration according to the ratio of the specific mass balance $\left(A-H_{s}\right)$. The second term describes the 'dilution' of the ice flux from the upstream unit.

The debris concentration above the initial concentration is assumed to cover the glacier surface. The actual debris height $H_{d}$ is a fraction of the critical glacier height $H_{c}$ (see Section 2.3) for simplicity taking account of the slope dependence and the minimum glacier thickness. This is expressed by the following equation:

$$
H_{d}=H_{c} \cdot\left(C_{g}-C_{0}\right)
$$

While this method is a strong approximation of the actual local debris conditions, it reproduces the basin-wide response of an increasing debris cover with increasing melt, typical for low-lying glacier termini. Since it is difficult to measure $C_{0}$ in reality, it may be calibrated by comparing debris accumulation on glaciers previously known to be debris-free (where other origins of debris can be ruled out) with ablation. Bozhinskiy et al. (1986) do this on the terminus of a glacier in the Caucasus and find a concentration of $0.12 \%$. This value is used in this study, while the sensitivity of the parameter will be tested in the range of 0-1\% in the Supplementary Material (Section S2.1).

\subsection{Case study catchments and data}

Two catchments similar in size and glacier coverage were chosen to test and validate the model (Table 1 and Figure 3). The catchment of the Upper Aksu River, Kyrgyzstan/NW China, is a data-scarce catchment typical for mountainous regions in Asia that the model was developed for. A second catchment, that of the Upper Rhone River, Switzerland was chosen to test the model under 'data-abundant' conditions. The catchments are briefly described below with list of input data in Table 2. Catchment details are further described in the Supplementary Material (Section S1).

The Upper Aksu catchment is located in the Inner Tien Shan mountain range in Central Asia, with the 
majority of the area in Kyrgyzstan but draining south into the Xinjiang Uighur Autonomous region of NW China. It includes the largest glacier system of the Tien Shan, the Northern and Southern Inylchek glaciers (Shangguan et al., 2015). The southern branch dams the near-annually outbursting Merzbacher Lake that has been widely discussed in the literature (Ng et al., 2007; Glazirin, 2010; Wortmann et al., 2014). About $45 \%$ of the catchment discharge is produced by glacier meltwater with a noticeable increase in discharge over the past 40 years (Krysanova et al., 2015; Pieczonka and Bolch, 2015). The catchment's extensive glacier cover has been shown to recede at a relatively small average rate of $-0.11 \pm 0.15 \% \mathrm{a}^{-1}$ for the period 1975 to 2008, while the observed mass balance between 1975 and 2000 was reported to be within the global average at $-350 \mathrm{~mm}$ w.e. $\mathrm{a}^{-1}$ (Pieczonka and Bolch, 2015).

The Upper Rhone catchment originates at the Rhone glacier in SW Switzerland and is terminated just before Lake Geneva at the gauging station Port du Scex. The catchment incorporates the Alps' largest glacier, the Great Aletsch Glacier and is one of Europe's most glaciated catchments (12\%). Between 1973 and 2010, its glacier area has shrunk by $-0.57 \% \mathrm{a}^{-1}$ on average (Paul, 2003; Fischer et al., 2014). Mass loss between 1980-2010 was shown to be heterogenous in magnitude ranging from $200-1200 \mathrm{~mm}$ w.e. $\mathrm{a}^{-1}$ with an average of $590 \mathrm{~mm}$ w.e. $\mathrm{a}^{-1}$ (Fischer et al., 2015).

A cumulated reservoir capacity of $1186 \times 10^{6} \mathrm{~m}^{3}$ is installed to date up to Lake Geneva (Meile et al. 2010). Although reservoirs are not a focus of this study, it was found essential to represent the largest reservoirs in the model to adequately simulate downstream discharge that is important for the calibration of the glacier model. The four largest dams (Lake Dix, Lake Emosson, Lake Mauvoisin and Lake Moiry; see Figure 3) were implemented using SWIM's reservoir model (Koch et al., 2013). Average monthly filling quotas of Switzerland from Schaefli (2005) were used, as they were shown to be highly correlated with most of the reservoirs in the catchment.

\subsection{Precipitation correction}

Mountainous catchments are highly susceptible to inaccurate precipitation observations due to a) low station density, b) high heterogeneity (i.e. short correlation distances) and c) a measurement bias in valleys. This is especially true for the Upper Aksu catchment, where an altitude-dependent precipitation correction was needed. The correction is based on findings by Aizen et al. (1995) and Immerzeel et al. (2015), introducing two additional calibration parameters for this catchment. The correction factor $f_{c}(z)$ is described by:

$$
f_{c}(z)=(c-1) \cdot \exp \left[-\left(\frac{a}{(c-1) \cdot 100}\right)^{2} \cdot(z-m)^{2}\right]+1
$$


with $c$ the maximum correction factor, $a$ the maximum precipitation elevation gradient and $m$ maximum precipitation elevation (kept constant at 5300 masl). More details are provided in the Supplementary Material (Section S1.1.1). Calibrated annual precipitation totals averaged over the catchments are $55 \%$ greater than the APHRODITE data suggests, agreeing well with independent investigations (Aizen et al., 1995 Duethmann et al., 2015).

Since the Upper Rhone catchment has a much higher density of meteorological stations, this correction was not necessary. Instead, all available precipitation data were interpolated via the Inverse-Distance-Weighting method and corrected by factors published in the Swiss Hydrological Atlas (Sevruk, 1985; Kirchhofer, 2000).

\subsection{Glacier initialisation}

Glaciers dynamics need decades to centuries to reach an equilibrium under a given stable climate. To take account of these long-term dynamics at the start of the modelling period, the ice cover has to be initialised by the model using a representative quasi-stable climate of this length. This ensures consistency between glacier cover and the driving data, as the interpolated climate data is inherently imprecise compared to the observed glacier cover. Also, the model processes and spatial routing structure are an imperfect representation of actual conditions, so that observed glacier areas and volumes can not be directly used as initial conditions.

For the proposed model, the glacier cover was initialised using a climate period in which the glacier mass balance is known to be close to 0, i.e. in a quasi-equilibrium state (Clarke et al., 2015; Marshall et al., 2011). Since this period is in most cases shorter than the time it takes for a glacier to reach an equilibrium, shorter periods are used successively for 200-1000 years. An initialisation period of 300 years was judged to be sufficient in both catchment, which is within the range of spin-up periods used in previous studies (Marshall et al., 2011; Naz et al., 2014). Mass balance records in the Tian Shan and the Alps have exhibited balanced or even positive budgets in the 1960s until the mid-1970s (Dyurgerov, 2010; Sorg et al., 2012; Dyurgerov and Meier, 1997; WGMS and UNEP, 2008). This is also true for reference glaciers in and close to the case study catchments of this study: The long-term mass balance records of the Griess glacier in the Rhone catchment show a mean of $-79 \mathrm{~mm} \mathrm{a}^{-1}$ between 1962-1980. For the Tien Shan, Dyurgerov (2010) suggests a regional average mass balance of $-82 \mathrm{~mm} \mathrm{a}^{-1}$ between 1960-1975 (also confirmed by Farinotti et al., 2015). These periods were chosen for the initialisation of the glacier cover in the respective catchments.

Glaciers are never in a perfect equilibrium state, as the two examples above show. Since the model initialisation assumes a perfect equilibrium, the residual mass balance must be represented by a calibration parameter that either adds or subtracts mass from the annual balance during the initialisation period. Clarke et al. (2015) use a similar bias approach in their mass balance model to initialise glaciers of western Canada. The residual mass balance parameter $b_{r}$ ensures that the equilibrium assumption of the initialisation does 
not lead to wrong parametrisations of accumulation (precipitation correction) or ablation (glacier melt).

\subsection{Multi-objective calibration and validation}

An overview of the parameters (introduced in the previous sections) that were used for the automatic calibration is given in Table 3 and an overview of manually adjusted parameters including the used values in Table 4. A calibration run consisted of a glacier initialisation and a subsequent 30 year model run. The model was calibrated to daily discharge observations, observed glacier area and catchment-wide, annual mass balances with approximately the same time coverage for each basin. For the Upper Rhone catchment, the mass balance calibration period is 1980-2010 to match the catchment-wide assessment of Fischer et al. (2015), while the hydrological calibration was only for the first half of that period (1980-1995) with the other half used for validation (split-sample approach). For the Upper Aksu catchment, the mass balance assessment of Pieczonka and Bolch (2015) is for the period 1975-1999, which was used as the glacier calibration period. Daily discharge data is only available for the period 1971-1987/1996 (Xiehela/Sary-Djaz). The available data was split in half with the first 8/12 years used for calibration and the rest for validation.

Four objective functions were chosen to rate the quality of the simulation. The quality of the discharge simulations is given by the common Nash-Sutcliffe Efficiency (Nash and Sutcliffe, 1970) and the bias in water balance. The model's accuracy in initialising the glacier area is quantified by the Root Mean Square Error (RMSE) between simulated and observed catchment-wide glacier hypsometry relative to the total observed area. The RMSE is also used to quantify the error in annual, catchment-wide glacier mass balances.

While manually calibrating the model to four objectives is possible, it is a painstaking and time-consuming exercise. After initial manual tests, the widely used automatic calibration algorithm, the Non-dominated Sorting Genetic Algorithm 2 or NSGA-2 (Deb et al., 2002), was chosen to provide multiple parameter sets. NSGA-2 employs evolutionary computation paired with the multi-objective Pareto optimality to rank and select well-performing parameter sets. The result is a collection of archived parameter sets that all produce 'good' results by at least one objective function. 'Good' here means that no other objective function can be improved without degrading any other, making them all 'Pareto-optimal' (together forming a Pareto front). It is up to the user to choose acceptable trade-offs between them.

A population size of 50 individuals was chosen that are concurrently evaluated over 100 generations, i.e. 5000 evaluations. Considering the 10-13 dimensional parameter space, these do not ensure finding all optimal solutions for the model. However, the method does provide an efficient way to finding some of them within a manageable computing time. The parallel evaluation reduces the calibration time to approximately the number of generations times model runtime, keeping the calibration time to 1-2 days rather than several weeks. To select acceptable trade-offs from the final archive of parameter sets, we chose the best 25 parameter 
sets by excluding results that do not meet the following minimal criteria: Nash-Sutcliffe Efficiency $>0.5$, percentage bias in the water balance $<20 \%$, absolute error of the glacier hypsometry as percent of total glacier area $<40 \%$ and RMSE of mass balance as percent of observed $<40 \%$. These values were successively improved (i.e. NSE increased and errors lowered) at $1 \%$ increments until the best 25 sets remain, for which median, minimum and maximum performance values are reported.

\section{Results}

From the Pareto-optimal solutions, the 25 best runs were selected following the approach described in Section 2.13. The calibrated parameter values (min., median, max.) are largely similar between the two catchments as expected for mid-latitude glaciers (Table 5). The drier climate of the Upper Aksu catchment becomes apparent in higher temperature lapse rates and slightly lower snow and ice melt factors. The precipitation correction was only applied to the Upper Aksu catchment and leads to a catchment-wide correction of 45-53\% (464-490 $\left.\mathrm{mm} \mathrm{a}^{-1}\right)$, in line with previous studies (Aizen et al., 1996 ; Duethmann et al. 2015). Table 6 provides an overview of the performance for both the hydrological and glaciological objective functions. A sensitivity analysis of the calibration parameters with regard to the four objective functions is given in the Supplementary Material (Section S2.1).

\subsection{Hydrological calibration and validation}

The daily simulated and observed discharge is shown in Figure 4 (over 3 years for better visibility) together with the day-of-year mean over the entire calibration/validation periods for both the outlet and the interior station. The hydrological model efficiency in the calibration period ranges from 0.60 to 0.90 with a range in bias of the water balance within $\pm 5.3 \%$ indicating a good model performance. However, differences in performance reflect the data quality and the impact of water regulation.

In the data-scarce Upper Aksu catchment, the model performance is significantly higher at the outlet station Xiehela with a NSE of 0.81-0.85, while in the much smaller subcatchment Sary-Djaz, it is only 0.600.72. The poor precipitation data seems to influences the performance more in the smaller catchment. In the Upper Rhone catchment, the best performing catchment is that of the smaller Blatten station with values of NSE of 0.85-0.90. The outlet station Port du Scex, however, shows a significant decline in performance with NSE values of $0.60-0.68$. This is most probably due to the many reservoirs that were only implemented on an average monthly basis, although day-to-day fluctuations (e.g. reduced flows on Sundays) are clearly visible (Figure 4). This performance pattern is repeated in the divergence from calibration to validation period. The performance of the Sary-Djaz catchment and the Port du Scex catchment is degrading more than at the other stations, but remains within acceptable limits (NSE values of $0.58-0.72$ and bias of $-11-+5 \%$ ). 


\subsection{Glacier initialisation}

The catchment-wide observed areas and estimated volumes are matched well by the modelled equilibrium of both area and volume over the initialisation period (Figure 5) and helped to rigorously correct the precipitation in conjunction with the observed and simulated catchment discharge. While uncertainties in the estimated 'observed' volumes (modelled by Duethmann et al. (2015) for the Upper Aksu catchment and Linsbauer et al. (2012) for the Rhone catchment) undoubtedly exist, the initialised volume is mainly controlled by the rheology parameter of the ice flow equation and the assumed shear stress of $10^{5} \mathrm{~Pa}$.

The area hypsometry is reproduced well by the model in both catchments (Figure 6 ). The sum of absolute residuals ranges from 7.2 to $31.2 \%$ of the total glacier area, while the total area error is within $-13.8-18.5 \%$. The largest mismatches exist in the data-scarce Sary-Djaz catchment, where insufficient driving data is likely affecting the accurate simulation of glacier area distributions. Discrepancies also exist in the elevation range with the largest glacier cover where the model overestimates cover in individual elevation zones by up to $25 \%$ in the Upper Aksu catchment and by up to $18 \%$ in the Rhone catchment.

\subsection{Mass balances and area changes}

The simulated mass balance was calibrated against reference glacier mass balance records, that were scaled by the catchment-wide geodetic mass balances provided by Pieczonka and Bolch (2015) for the Upper Aksu and by Fischer et al. (2015) for the Upper Rhone catchment. The comparison of both simulated and 'observed' mass balances is shown in Figure 7 including the parameter uncertainty ranges. Simulated and observed annual mass balances are generally in good agreement (Table 6). Parameter uncertainty ranges in the Upper Aksu catchment are at $0.03-0.04 \mathrm{mw} . \mathrm{a}^{-1}$ significantly smaller than the error of observations. This is not the case in the Upper Rhone catchment, where the parameter uncertainty range is $0.14-0.16 \mathrm{~m}$ w.e. $\mathrm{a}^{-1}$ and comparable to the uncertainties of observations. This is due to the fact that Fischer et al. (2015) used higher resolution elevation data (25m, DHM25 and SwissAlti3d), while Pieczonka and Bolch (2015) relied on the SRTM3 DEM (90m resolution) and Hexagon KH-9 stereo data.

Glacier area changes over the simulation period 1970-2000 in the Upper Aksu and 1980-2010 in the Upper Rhone catchment are shown in Figure 8. They are not part of the calibration, but are compared to geodetic area change values from the literature (Fischer et al., 2015; Pieczonka and Bolch, 2015). There is a good agreement in the Upper Aksu catchment where the parameter uncertainty range fully overlaps the error range of the observations. In the Upper Rhone, the observed shrinkage is slightly higher, but the uncertainty ranges overlap. The area changes in the much smaller Blatten catchment (Great Aletsch glacier) are significantly smaller than the catchment-wide values. This is in line with the catchment's mean 
ice thickness of $115 \mathrm{~m}$ Linsbauer et al. (2012) and large glacier tongue that make it less sensitive to area changes despite strong mass losses.

\subsection{Annual water balance and long-term annual discharge}

The hydrological effects of glacier changes are most evident in long-term river discharge. Trends in annual discharge may reflect changes in the glaciers' mass balance but also reflect changes in precipitation. For example, Pieczonka and Bolch (2015) estimate that 20\% of discharge increases in the Upper Aksu catchment are due to the glacier imbalance. Glacio-hydrological models are able to decompose those trends to understand changes in river discharge and project possible 'peak discharge' due to glacier decline.

Figure 9 shows annual runoff (annual discharge divided by catchment area) together with precipitation and glacier melt (distributed over the catchment) over the 30-year simulation period of the most glacierised catchments of both rivers terminated by Xiehela and Blatten station. Both show a good modelling fit including reproduced trends. However, comparing both catchments also exposes the data quality; the interannual variations are reproduced much better in the Upper Rhone and show some larger deviations in the 1990's in the Upper Aksu. This coincides with the decline in precipitation observations that contributed to the APHRODITE reanalysis set with the collapse of the Soviet Union.

Figure 9 also shows the annual precipitation and glacier melt distributed over the catchment area (not to be confused with mass balance, i.e. accumulation-ablation over the glacier area). Mean annual glacier melt amounts to $739 \pm 18 \mathrm{~mm} \mathrm{a}^{-1}\left(163 \pm 4 \mathrm{~mm} \mathrm{a}^{-1}\right.$ distributed over catchment area) in the Upper Aksu catchment and $1682 \pm 88 \mathrm{~mm} \mathrm{a}^{-1}\left(959 \pm 50 \mathrm{~mm} \mathrm{a}^{-1}\right)$ in the Upper Rhone (Blatten) catchment. In comparison, sublimation accounts for a mere $37.3 \pm 0.9 \mathrm{~mm} \mathrm{a}^{-1}\left(8.2 \pm 0.2 \mathrm{~mm} \mathrm{a}^{-1}\right)$ and $49.6 \pm 2.6 \mathrm{~mm} \mathrm{a}^{-1}\left(28.3 \pm 1.5 \mathrm{~mm} \mathrm{a}^{-1}\right)$ of ablation in both catchments respectively.

Both glacier melt and precipitation are the principal drivers of inter-annual variability of discharge, as their magnitudes are indicative of the year's weather. The increasing discharge in the Upper Aksu in the last 4 years is caused by both increasing glacier melt and precipitation, for example. Similarly, the increasing trend in discharge at the Blatten (Upper Rhone) station is driven by increasing glacier melt in the 2000s, while precipitation is generally lower than in the previous two decades (hence the strongly negative mass balances). Comparing glacier melt to discharge also highlights the importance of the glaciers in the catchment. The mean glacier melt to discharge ratio is $44 \%$ and $43 \%$ in the Xiehela and Blatten catchment respectively, although their glacierisation vary significantly with $22 \%$ and $57 \%$, respectively. 


\section{Discussion}

SWIM-G, the model presented here bridges the divide between semi-distributed, empirical glacio-hydrological catchment models and fully distributed, more physically based models for small scales. It offers a new representation of individual glaciers on the catchment scale without being computationally too demanding and excessively precise. The model integrates ice flow over the spatially adaptive glaciological response units, avoiding computationally expensive finite difference schemes such as those used by Clarke et al. (2015) or Seddik et al. (2012). It represents glacier dynamics of individual glaciers as distributed glacio-hydrological models have done, such as Naz et al. (2014) and Immerzeel et al. (2011), but can do so for much larger catchments at an intermediate resolution appropriate for the catchment hydrology. Previous semi-distributed or empirical approaches to bridge this scale gap such as Uhlmann et al. (2013) and Huss et al. (2010a) have made important advances in this regard, yet do not include a process-based description of glacier dynamics on an individual glacier basis. Some other important glaciological or hydrological processes (e.g. debris cover, sublimation, reservoirs) are so far also missing in these or similar models. While more physically-based (Naz et al., 2014; Clarke et al., 2015) approaches exist, the scope of our model lies in larger catchments, where those approaches fail due to their data and/or computational requirements. Its primary purpose will be to serve as a tool for integrated climate change impact assessments of glaciological and hydrological changes, making use of climate change scenarios, such as the scenario ensembles of CMIP5 (Taylor et al., 2011) of global climate models or regional scenarios from the CORDEX initiative (Giorgi and Gutowski, 2015).

Hydrological modelling of larger glacierised catchments is plagued with data scarcity, often yielding results with high uncertainty. However, recent advances in glaciological remote sensing (Gardelle et al., 2012; Fischer et al., 2015; Pieczonka and Bolch, 2015), in the modelling of climatic parameters (e.g. Maussion et al., 2014; Immerzeel et al., 2015) and the increasing availability of glaciological baseline data have helped to overcome some of these data gaps. More glacier outlines, mass balance and glacier thickness data from the global terrestrial network for glaciers (www.gtn-g.org) and other databases have become available to modellers. The model presented here attempts to incorporate these advances, while keeping the driving data to a minimum. It is calibrated not only to measured discharge, but also to glacier distribution and observed mass balance. A larger number and more diverse observations constrain the parameter ranges greatly, which is especially important for those parameters with the largest effects on discharge, i.e. precipitation correction and glacier melt. Our multi-objective calibration reduces the overall uncertainty of discharge simulations in mountainous catchments with insufficient observations. This contributes to other recent studies concerned with data scarcity, such as using remotely sensed snow cover data in conjunction with discharge (Duethmann et al., 2014), the output of regional climate models as weights for a discharge-based precipitation correction 
(Duethmann et al., 2014) or a precipitation correction solely based on a glacier equilibrium assumption (Immerzeel et al., 2012). Thus, the glacier dynamics module integrated into the hydrological model SWIM and the multi-objective calibration procedure are well adapted to data-scarce catchments with various kinds - yet limited - observations.

Another approach to overcome the data scarcity and to also formulate a comprehensive representation of glacier processes is the use of "expert parameters", i.e. those that are only constrained by expert knowledge, empirical values or point-based measurements (Winsemius et al., 2009). For example, the ratio of energy consumed by sublimation or the debris concentration in glaciers are constrained by values reported in the literature and transferred to the catchments at hand. Similarly, the thresholds used for the spatial disaggregation (elevation zone interval, hillslope threshold, minimum unit size) are empirical values and depend on the desired level of detail. These parameters are difficult to calibrate because they have little or indirect influences on the calibration objectives and may be easily compensated for by other more dominant parameters (Refsgaard, 1997). They are mostly unique to a particular catchment but constrained by ranges reported in the literature or by model results that are not part of the calibration. While using these parameters leads to a high risk of parameter equifinality and may seem like excessive complexity with high uncertainty (Beven, 2006), they are intended to make the model more robust on longer time scales (i.e. 30 to 100 years) and physically more complete than other empirical and conceptual models of mountain hydrology (Merz et al., 2011). The use of expert parameters allows the scarce information about not systematically observed processes to be included in the modelling, a type of parameter upscaling (Blöschl and Sivapalan, 1995) that is warranted where little to no data exists (Dornes et al., 2008; Krogh et al., 2014).

In cases where more observations of driving variables exist, the model could be extended to more physically based approaches of glacier processes, such as calculating the full energy balance for ablation or the inclusion of an explicit glacier sliding term (e.g. Weertman's sliding law in Immerzeel et al., 2011). However, this would only yield better results if reliable driving data for these approaches (radiation, humidity etc.) are available and can be spatially distributed over the entire catchment. Additional satellite-based observations for calibration such as snow extents (cf. Duethmann et al., 2014) could further improve the robustness of the simulations.

An important process considered in our model is the evolution of debris cover in response to glacier mass changes (Section 2.9 and Supplementary Material). This introduces a much discussed negative feedback into modelling of glaciers under climate change, i.e. the increased shielding of ice as glaciers retreat (Scherler et al. 2011; Kirkbride and Deline, 2013). The implementation here is a starting point for a more general treatment of debris on glaciers because so far the model only considers the relative effect of a negative mass balance on melt rates while absolute debris thicknesses are unknown at the catchment scale. The approach could be 
further developed by initialising debris cover along with the ice cover, effectively modelling debris thickness that could be verified against point observations. However, this would require finding a debris equilibrium between debris production and fallout rates. Although several processes governing debris production and deposition are understood (e.g. Hambrey et al., 2008), they have not been systematically described and the implementation has just started (e.g. Anderson and Anderson, 2016; Rowan et al., 2015) requiring further research.

Some processes were deliberately left out. For example, the influence of ice cliffs or supraglacial lakes on glacier melt was not considered although they occur frequently on debris-covered glaciers (Cuffey and Paterson, 2010; Juen et al., 2014). These hot spots of glacier melt may be significant on some glaciers but are of lesser importance than the shielding effect of debris cover (Sakai et al., 1998, 2000; Juen et al., 2014). It is nearly impossible to predict their occurrence, persistence and size at a catchment level as they are mostly erratic features. Similarly local processes that are also not considered are wind drifted snow, aerosol deposition, glacier surges and supraglacial evaporation (e.g. from supraglacial meltwater ponds and creeks). The limited influence of these processes on the catchment hydrology and glacier evolution clearly does not justify the difficulties of implementation and the added uncertainties. However, testing and including more debris processes may be part of future additions to the model.

\section{Conclusions}

A new catchment-wide glacier dynamics model was developed and integrated into the hydrological model SWIM (SWIM-G). It covers most glacier processes relevant to simulating catchment discharge including ice dynamics, debris melt-out and sublimation. This ensures robustness over long timescales and a range of climatic and glaciological settings, although it was primarily developed for data-scarce catchments of High Asia. The new approach to representing individual glaciers and their dynamics in a hydrological model bridges the gap between distributed, physically based glacier dynamics models - that are typically only applicable to single glaciers or small glacier groups - and large-scale empirical glacio-hydrological models. This allows for accurate and integrated glaciological and hydrological assessments of entire, highly glacierised catchments. The intermediate complexity enables ensemble modelling approaches for calibration and scenario analysis by reducing computing time compared to fully distributed glacier models.

SWIM-G was implemented and validated in a data-scarce catchment in Kyrgyzstan/NW China and a data-abundant catchment in Switzerland. The calibration yielded good results compared to both discharge and glaciological observations, but performance depends on data quality - precipitation observations in particular. The model was automatically calibrated using a multi-objective evolutionary optimisation 
that is widely used in hydrological modelling. The parameter uncertainty is comparable to uncertainties of glaciological observations (e.g. glaciological or geodetic area and mass balance observations) but may become larger over longer simulation periods. The application to the arid Upper Aksu catchment shows that adequately simulating glacier dynamics (including accurate rates of accumulation and ablation) is vital to properly model this and similar river basins due to their high contribution of glacier melt to discharge. The intermediate complexity of the developed glacio-hydrological model means that it is well adapted to large, partially glacierised and data-scarce catchments, as they are often found in High Asia and other mountain ranges of the world. Its main purpose is to serve as a model for long-term glacio-hydrological climate change impact assessments of IPCC scenarios for the 21st century.

\section{Acknowledgements}

This study was conducted within the project SuMaRiO (Sustainable Management of River Oases along the Tarim River; http://www.sumario.de/), funded by the German Federal Ministry of Education and Research (BMBF grants 01LL0918J and 01LL0918B). T. Bolch acknowledges funding by Deutsche Forschungsgemeinschaft (DFG, Code BO3199/2-1). The authors gratefully acknowledge the European Regional Development Fund (ERDF), the German Federal Ministry of Education and Research and the Land Brandenburg for supporting this project by providing resources on the high performance computer system at the Potsdam Institute for Climate Impact Research.

\section{References}

Aizen, V., Aizen, E., Melack, J., 1995. Climate, snow cover, glaciers, and runoff in the Tien Shan, Central Asia. JAWRA Journal of the American Water Resources Association 31, 1113-1129. doi:10.1111/j. 1752-1688.1995.tb03426.x.

Aizen, V.B., Aizen, E.M., Melack, J.M., 1996. Precipitation, melt and runoff in the northern Tien Shan. Journal of Hydrology 186, 229-251. doi:10.1016/S0022-1694(96)03022-3

Anderson, L.S., Anderson, R.S., 2016. Modeling debris-covered glaciers: response to steady debris deposition. The Cryosphere 10, 1105-1124. URL: https://www .the-cryosphere.net/10/1105/2016/, doi:10.5194/ tc-10-1105-2016

Arnold, J.G., Allen, P.M., Bernhardt, G., 1993. A comprehensive surface-groundwater flow model. Journal of Hydrology 142, 47-69. doi: 10.1016/0022-1694(93) 90004-S 
Beven, K., 2006. A manifesto for the equifinality thesis. Journal of Hydrology 320, 18-36. doi:10.1016/j . jhydrol.2005.07.007

Bishop, M.P., Shroder Jr., J.F., Colby, J.D., 2003. Remote sensing and geomorphometry for studying relief production in high mountains. Geomorphology 55, 345-361. doi:10.1016/S0169-555X(03) 00149-1

Blöschl, G., Sivapalan, M., 1995. Scale issues in hydrological modelling: A review. Hydrological Processes 9, 251-290. doi:10.1002/hyp.3360090305

Bolch, T., 2011. Debris, in: Singh, V.P., Singh, P., Haritashya, U.K. (Eds.), Encyclopedia of Snow, Ice and Glaciers. Springer Netherlands. Encyclopedia of Earth Sciences Series, pp. 176-178.

Bolch, T., Kulkarni, A., Kääb, A., Huggel, C., Paul, F., Cogley, J.G., Frey, H., Kargel, J.S., Fujita, K., Scheel, M., Bajracharya, S., Stoffel, M., 2012. The State and Fate of Himalayan Glaciers. Science 336, 310-314. doi: 10.1126/science.1215828

Bozhinskiy, A., Krass, M., Popovnin, V., 1986. Role of debris cover in the thermal physics of glaciers. Journal of Glaciology 32, 255-266.

Clarke, G.K.C., Jarosch, A.H., Anslow, F.S., Radić, V., Menounos, B., 2015. Projected deglaciation of western Canada in the twenty-first century. Nature Geoscience advance online publication. doi:10.1038/ ngeo2407

Cronin, T., 2000. Classifying hills and valleys in digitized terrain. Photogrammetric engineering and remote sensing 66, 1129-1137.

Cuffey, K.M., Paterson, W.S.B., 2010. The Physics of Glaciers. Elsevier, Amsterdam. 00292.

Deb, K., Pratap, A., Agarwal, S., Meyarivan, T., 2002. A fast and elitist multiobjective genetic algorithm: NSGA-II. IEEE Transactions on Evolutionary Computation 6, 182-197. doi:10.1109/4235.996017.

Dickerson-Lange, S.E., Mitchell, R., 2014. Modeling the effects of climate change projections on streamflow in the Nooksack River basin, Northwest Washington. Hydrological Processes 28, 5236-5250. doi:10.1002/ hyp. 10012.

Dietrich, W.E., Reiss, R., Hsu, M.L., Montgomery, D.R., 1995. A process-based model for colluvial soil depth and shallow landsliding using digital elevation data. Hydrological Processes 9, 383-400. doi:10. 1002/hyp. 3360090311 
Dornes, P.F., Pomeroy, J.W., Pietroniro, A., Carey, S.K., Quinton, W.L., 2008. Influence of landscape aggregation in modelling snow-cover ablation and snowmelt runoff in a sub-arctic mountainous environment. Hydrological Sciences Journal 53, 725-740. doi:10.1623/hysj.53.4.725

Dudeja, D., 2011. Gelisols, in: Singh, V.P., Singh, P., Haritashya, U.K. (Eds.), Encyclopedia of Snow, Ice and Glaciers. Springer Netherlands. Encyclopedia of Earth Sciences Series, pp. 313-313. 00000.

Duethmann, D., Bolch, T., Farinotti, D., Kriegel, D., Vorogushyn, S., Merz, B., Pieczonka, T., Jiang, T., Su, B., Güntner, A., 2015. Attribution of streamflow trends in snow- and glacier melt dominated catchments of the Tarim River, Central Asia. Water Resources Research , 4727-4750doi:10.1002/2014WR016716

Duethmann, D., Peters, J., Blume, T., Vorogushyn, S., Güntner, A., 2014. The value of satellite-derived snow cover images for calibrating a hydrological model in snow-dominated catchments in Central Asia. Water Resources Research 50, 2002-2021. doi:10.1002/2013WR014382.

Duethmann, D., Zimmer, J., Gafurov, A., Güntner, A., Kriegel, D., Merz, B., Vorogushyn, S., 2013. Evaluation of areal precipitation estimates based on downscaled reanalysis and station data by hydrological modelling. Hydrol. Earth Syst. Sci. 17, 2415-2434. doi:10.5194/hess-17-2415-2013

Dyurgerov, M.B., 2010. Reanalysis of Glacier Changes: From the IGY to the IPY, 1960-2008. Number 108 in Data of Glaciological Studies, Glaciological Association, Geographical Institute of the Russian Academy of Sciences, Moscow.

Dyurgerov, M.B., Meier, M.F., 1997. Mass Balance of Mountain and Subpolar Glaciers: A New Global Assessment for 1961-1990. Arctic and Alpine Research 29, 379-391. doi:10.2307/1551986.

FAO, 2011. Crop calendar. http://www.fao.org/agriculture/seed/cropcalendar/.

Farinotti, D., Longuevergne, L., Moholdt, G., Duethmann, D., Mölg, T., Bolch, T., Vorogushyn, S., Güntner, A., 2015. Substantial glacier mass loss in the Tien Shan over the past 50 years. Nature Geoscience 8, 716-722. doi: $10.1038 /$ ngeo2513

Finger, D., Pellicciotti, F., Konz, M., Rimkus, S., Burlando, P., 2011. The value of glacier mass balance, satellite snow cover images, and hourly discharge for improving the performance of a physically based distributed hydrological model. Water Resources Research 47, W07519. doi:10.1029/2010WR009824.

Fischer, M., Huss, M., Barboux, C., Hoelzle, M., 2014. The New Swiss Glacier Inventory SGI2010: Relevance of Using High-Resolution Source Data in Areas Dominated by Very Small Glaciers. Arctic, Antarctic, and Alpine Research 46, 933-945. doi:10.1657/1938-4246-46.4.933. 
Fischer, M., Huss, M., Hoelzle, M., 2015. Surface elevation and mass changes of all Swiss glaciers 1980-2010.

The Cryosphere 9, 525-540. doi:10.5194/tc-9-525-2015

Frey, H., Machguth, H., Huss, M., Huggel, C., Bajracharya, S., Bolch, T., Kulkarni, A., Linsbauer, A., Salzmann, N., Stoffel, M., 2014. Estimating the volume of glaciers in the Himalayan-Karakoram region using different methods. The Cryosphere 8, 2313-2333. doi:10.5194/tc-8-2313-2014.

Friedl, M.A., McIver, D.K., Hodges, J.C.F., Zhang, X.Y., Muchoney, D., Strahler, A.H., Woodcock, C.E., Gopal, S., Schneider, A., Cooper, A., Baccini, A., Gao, F., Schaaf, C., 2002. Global land cover mapping from MODIS: Algorithms and early results. Remote Sensing of Environment 83, 287-302. doi:10.1016/ S0034-4257(02) 00078-0

Gardelle, J., Berthier, E., Arnaud, Y., 2012. Slight mass gain of Karakoram glaciers in the early twenty-first century. Nature Geoscience 5, 322-325. doi:10.1038/ngeo1450.

Gascoin, S., Kinnard, C., Ponce, R., Lhermitte, S., MacDonell, S., Rabatel, A., 2011. Glacier contribution to streamflow in two headwaters of the Huasco River, Dry Andes of Chile. The Cryosphere 5, 1099-1113. doi: $10.5194 /$ tc-5-1099-2011.

Gelfan, A., Pomeroy, J., Kuchment, L., 2004. Modeling forest cover influences on snow accumulation, sublimation, and melt. Journal of Hydrometeorology 5, 785-803.

Gill, M.A., 1978. Flood routing by the Muskingum method. Journal of Hydrology 36, 353-363. doi: 10. 1016/0022-1694(78)90153-1.

Giorgi, F., Gutowski, W.J., 2015. Regional Dynamical Downscaling and the CORDEX Initiative. Annual Review of Environment and Resources 40, 467-490. doi:10.1146/annurev-environ-102014-021217.

Glazirin, G., 2010. A century of investigations on outbursts of the ice-dammed Lake Merzbacher (Central Tien Shan). Austrian Journal of Earth Sciences 103, 171-179.

GRDC, 2016. The Global Runoff Data Centre. Technical Report. Bundesanstalt für Gewässerkunde. 56068 Koblenz, Germany.

Haeberli, W., Hoelzle, M., 1995. Application of inventory data for estimating characteristics of and regional climate-change effects on mountain glaciers: A pilot study from the European Alps. Annals of Glaciology 21, 206-212. 
Hagg, W., Braun, L.N., Kuhn, M., Nesgaard, T.I., 2007. Modelling of hydrological response to climate change in glacierized Central Asian catchments. Journal of Hydrology 332, 40-53. doi:10.1016/j.jhydrol. 2006. 06.021

Hagg, W., Mayer, C., Lambrecht, A., Helm, A., 2008. Sub-Debris Melt Rates on Southern Inylchek Glacier, Central Tian Shan. Geografiska Annaler: Series A, Physical Geography 90, 55-63. doi:10.1111/j. $1468-0459.2008 .00333 . x$

Hambrey, M.J., Quincey, D.J., Glasser, N.F., Reynolds, J.M., Richardson, S.J., Clemmens, S., 2008. Sedimentological, geomorphological and dynamic context of debris-mantled glaciers, Mount Everest (Sagarmatha) region, Nepal. Quaternary Science Reviews 27, 2361-2389. doi:10.1016/j.quascirev.2008.08. 010.

Hattermann, F., Weiland, M., Huang, S., Krysanova, V., Kundzewicz, Z., 2011. Model-Supported Impact Assessment for the Water Sector in Central Germany Under Climate Change-A Case Study. Water Resources Management 25, 3113-3134. doi:10.1007/s11269-011-9848-4.

Heimsath, A.M., E. Dietrich, W., Nishiizumi, K., Finkel, R.C., 1999. Cosmogenic nuclides, topography, and the spatial variation of soil depth. Geomorphology 27, 151-172. doi:10.1016/S0169-555X (98)00095-6.

Hock, R., 2003. Temperature index melt modelling in mountain areas. Journal of Hydrology 282, 104-115. doi:10.1016/S0022-1694(03)00257-9. 00406.

Hock, R., 2005. Glacier melt: A review of processes and their modelling. Progress in Physical Geography 29, 362 -391. doi: 10.1191/0309133305pp453ra

Hock, R., Holmgren, B., 2005. A distributed surface energy-balance model for complex topography and its application to Storglaciären, Sweden. Journal of Glaciology 51, 25-36. doi:10.3189/172756505781829566

Hock, R., Hooke, R.L., 1993. Evolution of the internal drainage system in the lower part of the ablation area of Storglaci?Ären, Sweden. Geological Society of America Bulletin 105, 537-546. doi:10.1130/ 0016-7606 (1993) 105<0537:EOTIDS>2.3.C0;2.

Huang, S., Hattermann, F.F., Krysanova, V., Bronstert, A., 2013a. Projections of climate change impacts on river flood conditions in Germany by combining three different RCMs with a regional eco-hydrological model. Climatic Change 116, 631-663. doi:10.1007/s10584-012-0586-2.

Huang, S., Krysanova, V., Hattermann, F.F., 2013b. Projection of low flow conditions in Germany under climate change by combining three RCMs and a regional hydrological model. Acta Geophysica 61, 151-193. doi: $10.2478 /$ s11600-012-0065-1 
Huang, S., Krysanova, V., Österle, H., Hattermann, F.F., 2010. Simulation of spatiotemporal dynamics of water fluxes in Germany under climate change. Hydrological Processes 24, 3289-3306. doi:10.1002/hyp. 7753.

Huss, M., Farinotti, D., Bauder, A., Funk, M., 2008. Modelling runoff from highly glacierized alpine drainage basins in a changing climate. Hydrological Processes 22, 3888-3902. doi:10.1002/hyp.7055.

Huss, M., Jouvet, G., Farinotti, D., Bauder, A., 2010a. Future high-mountain hydrology: A new parameterization of glacier retreat. Hydrol. Earth Syst. Sci. 14, 815-829. doi:10.5194/hess-14-815-2010.

Huss, M., Usselmann, S., Farinotti, D., Bauder, A., 2010b. Glacier mass balance in the south-eastern Swiss Alps since 1900 and perspectives for the future. Erdkunde 64, 119-140. 00025.

Immerzeel, W.W., van Beek, L.P.H., Bierkens, M.F.P., 2010. Climate Change Will Affect the Asian Water Towers. Science 328, 1382-1385. doi:10.1126/science.1183188

Immerzeel, W.W., van Beek, L.P.H., Konz, M., Shrestha, A.B., Bierkens, M.F.P., 2011. Hydrological response to climate change in a glacierized catchment in the Himalayas. Climatic Change 110, 721-736. doi: 10. $1007 / \mathrm{s} 10584-011-0143-4$

Immerzeel, W.W., Pellicciotti, F., Shrestha, A.B., 2012. Glaciers as a Proxy to Quantify the Spatial Distribution of Precipitation in the Hunza Basin. Mountain Research and Development 32, 30-38. doi:10.1659/MRD-JOURNAL-D-11-00097.1, 00023.

Immerzeel, W.W., Petersen, L., Ragettli, S., Pellicciotti, F., 2014. The importance of observed gradients of air temperature and precipitation for modeling runoff from a glacierized watershed in the Nepalese Himalayas. Water Resources Research 50, 2212-2226. doi: 10.1002/2013WR014506. 00005.

Immerzeel, W.W., Wanders, N., Lutz, A.F., Shea, J.M., Bierkens, M.F.P., 2015. Reconciling high-altitude precipitation in the upper Indus basin with glacier mass balances and runoff. Hydrol. Earth Syst. Sci. 19, 4673-4687. doi:10.5194/hess-19-4673-2015.

Jansson, P., Hock, R., Schneider, T., 2003. The concept of glacier storage: A review. Journal of Hydrology 282, 116-129. doi: 10.1016/S0022-1694(03)00258-0

Jarvis, A., Reuter, H., Nelson, A., Guevara, E., 2007. Hole-filled seamless SRTM data.

Jost, G., Moore, R.D., Menounos, B., Wheate, R., 2012. Quantifying the contribution of glacier runoff to streamflow in the upper Columbia River Basin, Canada. Hydrol. Earth Syst. Sci. 16, 849-860. doi: 10. 5194/hess-16-849-2012 
Juen, M., Mayer, C., Lambrecht, A., Han, H., Liu, S., 2014. Impact of varying debris cover thickness on ablation: A case study for Koxkar Glacier in the Tien Shan. The Cryosphere 8, 377-386. doi:10.5194/ tc-8-377-2014

Kaser, G., 2001. Glacier-climate interaction at low latitudes. Journal of Glaciology 47, 195-204. doi: 10. $3189 / 172756501781832296$

Kirchhofer, W. (Ed.), 2000. Klimaatlas Der Schweiz. Schweizerische Meteorologische Anstalt, Wabern.

Kirkbride, M.P., Deline, P., 2013. The formation of supraglacial debris covers by primary dispersal from transverse englacial debris bands. Earth Surface Processes and Landforms 38, 1779-1792. doi:10.1002/ esp. 3416

Klemeš, V., 1990. The modelling of mountain hydrology: The ultimate challenge, in: Hydrology of Mountainous Areas. IAHS. volume 190, pp. 29-43.

Koch, H., Liersch, S., Hattermann, F.F., 2013. Integrating water resources management in eco-hydrological modelling. Water Science \& Technology 67. doi:10.2166/wst.2013.022.

Kraaijenbrink, P.D.A., Bierkens, M.F.P., Lutz, A.F., Immerzeel, W.W., 2017. Impact of a global temperature rise of 1.5 degrees Celsius on Asiaâs glaciers. Nature 549, 257-260. URL: https://www.nature.com/ articles/nature23878, doi: $10.1038 /$ nature23878

Krogh, S.A., Pomeroy, J.W., McPhee, J., 2014. Physically Based Mountain Hydrological Modeling Using Reanalysis Data in Patagonia. Journal of Hydrometeorology 16, 172-193. doi: 10.1175/JHM-D-13-0178.1

Krysanova, V., Hattermann, F., Wechsung, F., 2005. Development of the ecohydrological model SWIM for regional impact studies and vulnerability assessment. Hydrological Processes 19, 763-783. doi:10.1002/ hyp. 5619

Krysanova, V., Müller-Wohlfeil, D., Becker, A., 1998. Development and test of a spatially distributed hydrological/water quality model for mesoscale watersheds. Ecological Modelling 106, 261-289. doi: 10. 1016/S0304-3800(97)00204-4, 00306.

Krysanova, V., Wechsung, F., 2000. SWIM Manual. Technical Report.

Krysanova, V., Wortmann, M., Bolch, T., Merz, B., Duethmann, D., Walter, J., Huang, S., Tong, J., Buda, S., Kundzewicz, Z.W., 2015. Analysis of current trends in climate parameters, river discharge and glaciers in the Aksu River basin (Central Asia). Hydrological Sciences Journal 60, 566-590. doi:10.1080/ 02626667.2014 .925559 
Liersch, S., Cools, J., Kone, B., Koch, H., Diallo, M., Reinhardt, J., Fournet, S., Aich, V., Hattermann, F., 2012. Vulnerability of rice production in the Inner Niger Delta to water resources management under climate variability and change. Environmental Science \& Policy doi:10.1016/j.envsci.2012.10.014 00003.

Lindström, G., Johansson, B., Persson, M., Gardelin, M., Bergström, S., 1997. Development and test of the distributed HBV-96 hydrological model. Journal of Hydrology 201, 272-288. doi:10.1016/ S0022-1694(97) 00041-3

Linsbauer, A., Paul, F., Haeberli, W., 2012. Modeling glacier thickness distribution and bed topography over entire mountain ranges with GlabTop: Application of a fast and robust approach. Journal of Geophysical Research: Earth Surface 117, F03007. doi:10.1029/2011JF002313

Luo, Y., Arnold, J., Liu, S., Wang, X., Chen, X., 2013. Inclusion of glacier processes for distributed hydrological modeling at basin scale with application to a watershed in Tianshan Mountains, northwest China. Journal of Hydrology 477, 72-85. doi:10.1016/j · jhydrol.2012.11.005

Marshall, S.J., Clarke, G.K.C., 1999. Ice sheet inception: Subgrid hypsometric parameterization of mass balance in an ice sheet model. Climate Dynamics 15, 533-550. doi:10.1007/s003820050298. 00058.

Marshall, S.J., White, E.C., Demuth, M.N., Bolch, T., Wheate, R., Menounos, B., Beedle, M.J., Shea, J.M., 2011. Glacier Water Resources on the Eastern Slopes of the Canadian Rocky Mountains. Canadian Water Resources Journal / Revue canadienne des ressources hydriques 36, 109-134. doi:10.4296/cwrj3602823 00027.

Mattson, L., 1993. Ablation on debris covered glaciers: An example from the Rakhiot Glacier, Panjab, Himalaya. IAHS publication 218, 289-296. 00125.

Maussion, F., Scherer, D., Mölg, T., Collier, E., Curio, J., Finkelnburg, R., 2014. Precipitation Seasonality and Variability over the Tibetan Plateau as Resolved by the High Asia Reanalysis. Journal of Climate 27, 1910-1927. doi:10.1175/JCLI-D-13-00282.1.

Meile, T., Boillat, J.L., Schleiss, A.J., 2010. Hydropeaking indicators for characterization of the Upper-Rhone River in Switzerland. Aquatic Sciences 73, 171-182. doi:10.1007/s00027-010-0154-7

Merz, R., Parajka, J., Blöschl, G., 2011. Time stability of catchment model parameters: Implications for climate impact analyses. Water Resources Research 47, W02531. doi:10.1029/2010WR009505. 
Mölg, T., Cullen, N.J., Kaser, G., 2009. Solar radiation, cloudiness and longwave radiation over low-latitude glaciers: Implications for mass-balance modelling. Journal of Glaciology 55, 292-302. doi:10.3189/ 002214309788608822

Nash, J., Sutcliffe, J., 1970. River flow forecasting through conceptual models part I - A discussion of principles. Journal of Hydrology 10, 282-290. doi:10.1016/0022-1694(70)90255-6

Naz, B.S., Frans, C.D., Clarke, G.K.C., Burns, P., Lettenmaier, D.P., 2014. Modeling the effect of glacier recession on streamflow response using a coupled glacio-hydrological model. Hydrol. Earth Syst. Sci. 18, 787-802. doi: 10.5194/hess-18-787-2014

Ng, F., Liu, S., Mavlyudov, B., Wang, Y., 2007. Climatic control on the peak discharge of glacier outburst floods. Geophysical Research Letters 34, L21503. doi:10.1029/2007GL031426

Nicholson, L., Benn, D.I., 2006. Calculating ice melt beneath a debris layer using meteorological data. Journal of Glaciology 52, 463-470. doi:10.3189/172756506781828584 00078.

Oesterle, H., Gerstengarbe, F., Werner, P., 2003. Homogenisierung und Aktualisierung des Klimadatensatzes des Climate Research Unit der Universität of East Anglia. Norwich: University of East Anglia .

Osmonov, A., Bolch, T., Xi, C., Kurban, A., Guo, W., 2013. Glacier characteristics and changes in the Sary-Jaz River Basin (Central Tien Shan, Kyrgyzstan) - 1990-2010. Remote Sensing Letters 4, 725-734. doi: $10.1080 / 2150704 X .2013 .789146$

Paul, F., 2003. The new Swiss glacier inventory 2000: Application of Remote Sensing and GIS. Ph.D. thesis. Department of Geography, University of Zurich.

Paul, F., 2010. The influence of changes in glacier extent and surface elevation on modeled mass balance. The Cryosphere 4, 569-581. doi:10.5194/tc-4-569-2010

Peel, M.C., Blöschl, G., 2011. Hydrological modelling in a changing world. Progress in Physical Geography 35, 249-261. doi:10.1177/0309133311402550

Pellicciotti, F., Brock, B., Strasser, U., Burlando, P., Funk, M., Corripio, J., 2005. An enhanced temperatureindex glacier melt model including the shortwave radiation balance: Development and testing for Haut Glacier d'Arolla, Switzerland. Journal of Glaciology 51, 573-587. doi:10.3189/172756505781829124 00131. 
Pellicciotti, F., Buergi, C., Immerzeel, W.W., Konz, M., Shrestha, A.B., 2012. Challenges and Uncertainties in Hydrological Modeling of Remote Hindu Kush-Karakoram-Himalayan (HKH) Basins: Suggestions for Calibration Strategies. Mountain Research and Development 32, 39-50. doi:10.1659/ MRD- JOURNAL-D-11-00092.1

Pieczonka, T., Bolch, T., 2015. Region-wide glacier mass budgets and area changes for the Central Tien Shan between 1975 and 1999 using Hexagon KH-9 imagery. Global and Planetary Change 128, 1-13. doi: 10.1016/j.gloplacha.2014.11.014

Priestley, C.H.B., Taylor, R.J., 1972. On the Assessment of Surface Heat Flux and Evaporation Using Large-Scale Parameters. Monthly Weather Review 100, 81-92. doi:10.1175/1520-0493(1972) 100<0081: OTAOSH $>2.3 . \mathrm{CO} ; 2$

Quick, M.C., Pipes, A., 1977. U.B.C. WATERSHED MODEL / Le modèle du bassin versant U.C.B. Hydrological Sciences Bulletin 22, 153-161. doi:10.1080/02626667709491701

Rasemann, S., Schmidt, J., Schrott, L., Dikau, R., 2004. Geomorphometry in Mountain Terrain, in: Geographic Information Science and Mountain Geomorphology. Springer Science \& Business Media, pp. $101-137$.

Refsgaard, J.C., 1997. Parameterisation, calibration and validation of distributed hydrological models. Journal of Hydrology 198, 69-97. doi:10.1016/S0022-1694(96)03329-X.

Rowan, A.V., Egholm, D.L., Quincey, D.J., Glasser, N.F., 2015. Modelling the feedbacks between mass balance, ice flow and debris transport to predict the response to climate change of debris-covered glaciers in the Himalaya. Earth and Planetary Science Letters 430, 427-438. doi:10.1016/j.eps1.2015.09.004

Sakai, A., Nakawo, M., Fujita, K., 1998. Melt rate of ice cliffs on the Lirung Glacier, Nepal Himalayas, 1996. Bulletin of glacier research , 57-66.

Sakai, A., Takeuchi, N., Fujita, K., Nakawo, M., 2000. Role of supraglacial ponds in the ablation process of a debris-covered glacier in the Nepal Himalayas. IAHS-AISH publication , 119-130.

Sanzana, P., Jankowfsky, S., Branger, F., Braud, I., Vargas, X., Hitschfeld, N., GironÃ $j$ s, J., 2013. Computerassisted mesh generation based on hydrological response units for distributed hydrological modeling. Computers \& Geosciences 57, 32-43. URL: http://www.sciencedirect.com/science/article/pii/ S0098300413000526, doi:10.1016/j.cageo.2013.02.006. bibtex: sanzana2013. 
Schaefli, B., 2005. Quantification of Modelling Uncertainties in Climate Change Impact Studies on Water Resources: Application to a Glacier-Fed Hydropower Production System in the Swiss Alps. Ph.D. thesis. École polytechnique fédérale de Lausanne. Lausanne.

Schaefli, B., Hingray, B., Niggli, M., Musy, A., 2005. A conceptual glacio-hydrological model for high mountainous catchments. Hydrology and Earth System Sciences 9, 95 - 109. 00124.

Scherler, D., Bookhagen, B., Strecker, M.R., 2011. Spatially variable response of Himalayan glaciers to climate change affected by debris cover. Nature Geoscience 4, 156-159. doi:10.1038/ngeo1068

Schweizer, J., Bruce Jamieson, J., Schneebeli, M., 2003. Snow avalanche formation. Reviews of Geophysics 41, 1016. doi:10.1029/2002RG000123

Seddik, H., Greve, R., Zwinger, T., Gillet-Chaulet, F., Gagliardini, O., 2012. Simulations of the Greenland ice sheet 100 years into the future with the full Stokes model Elmer/Ice. Journal of Glaciology 58, 427-440. doi:10.3189/2012JoG11J177.

Sevruk, B., 1985. Systematischer Niederschlagsmessfehler in der Schweiz. Beiträge zur Geologie der Schweiz-Hydrologie 31, 65-75.

Shangguan, D.H., Bolch, T., Ding, Y.J., Kröhnert, M., Pieczonka, T., Wetzel, H.U., Liu, S.Y., 2015. Mass changes of Southern and Northern Inylchek Glacier, Central Tian Shan, Kyrgyzstan, during 1975 and 2007 derived from remote sensing data. The Cryosphere 9, 703-717. doi:10.5194/tc-9-703-2015.

Sorg, A., Bolch, T., Stoffel, M., Solomina, O., Beniston, M., 2012. Climate change impacts on glaciers and runoff in Tien Shan (Central Asia). Nature Climate Change 2, 725-731. doi: 10.1038/nclimate1592.

Taylor, K.E., Stouffer, R.J., Meehl, G.A., 2011. An Overview of CMIP5 and the Experiment Design. Bulletin of the American Meteorological Society 93, 485-498. doi:10.1175/BAMS-D-11-00094.1

Uhlmann, B., Jordan, F., Beniston, M., 2013. Modelling runoff in a Swiss glacierized catchment-part I: Methodology and application in the Findelen basin under a long-lasting stable climate. International Journal of Climatology 33, 1293-1300. doi:10.1002/joc.3501.

Vieli, A., 2015. Glacier change: Dynamic projections. Nature Geoscience 8, 332-333. doi:10.1038/ngeo2425

Weedon, G.P., Gomes, S., Viterbo, P., Shuttleworth, W.J., Blyth, E., Oesterle, H., Adam, J.C., Bellouin, N., Boucher, O., Best, M., 2011. Creation of the WATCH Forcing Data and Its Use to Assess Global and Regional Reference Crop Evaporation over Land during the Twentieth Century. Journal of Hydrometeorology 12, 823-848. doi:10.1175/2011JHM1369.1. 00081. 
WGMS, UNEP, 2008. Global Glacier Changes: Facts and Figures. World Glacier Monitoring Service, Zürich.

Winkler, M., Juen, I., Mölg, T., Wagnon, P., Gómez, J., Kaser, G., 2009. Measured and modelled sublimation on the tropical Glaciar Artesonraju, Perú. The Cryosphere 3, 21-30. doi:10.5194/tc-3-21-2009.

Winsemius, H.C., Schaefli, B., Montanari, A., Savenije, H.H.G., 2009. On the calibration of hydrological models in ungauged basins: A framework for integrating hard and soft hydrological information. Water Resources Research 45, W12422. doi:10.1029/2009WR007706

Wortmann, M., Krysanova, V., Kundzewicz, Z.W., Su, B., Li, X., 2014. Assessing the influence of the Merzbacher Lake outburst floods on discharge using the hydrological model SWIM in the Aksu headwaters, Kyrgyzstan/NW China. Hydrological Processes 28, 6337-6350. doi:10.1002/hyp.10118.

Yatagai, A., Kamiguchi, K., Arakawa, O., Hamada, A., Yasutomi, N., Kitoh, A., 2012. APHRODITE: Constructing a Long-Term Daily Gridded Precipitation Dataset for Asia Based on a Dense Network of Rain Gauges. Bulletin of the American Meteorological Society 93, 1401-1415. doi:10.1175/BAMS-D-11-00122 . 1. 00128 .

Zhang, Y., Liu, S., Ding, Y., 2006. Observed degree-day factors and their spatial variation on glaciers in western China. Annals of Glaciology 43, 301-306. doi:10.3189/172756406781811952. 00037.

Östrem, G., 1959. Ice Melting under a Thin Layer of Moraine, and the Existence of Ice Cores in Moraine Ridges. Geografiska Annaler 41, 228-230. 
Table 1: Catchment details according to the gauging stations used for calibration; drainage area, mean discharge Q as annual mean and summer mean for the month June to August (over all available data) and glacier cover. See Tab. Table 2 for sources.

\begin{tabular}{llrrrr}
\hline Gauge station & River & $\begin{array}{r}\text { Area } \\
\mathrm{km}^{2}\end{array}$ & $\begin{array}{r}\mathrm{Q}_{a} \\
\mathrm{~m}^{3} s^{-1}\end{array}$ & $\begin{array}{r}\mathrm{Q}_{J J A} \\
\mathrm{~m}^{3} s^{-1}\end{array}$ & $\begin{array}{r}\text { Glacier } \\
\%\end{array}$ \\
\hline Upper Aksu & & & & & \\
Xiehela & Kumarik R. & 12991 & 151.8 & 406.6 & 22 \\
Sary-Djaz & Sary-Djaz R. & 1927 & 37.4 & 91.3 & 18 \\
\hline Upper Rhone & & & & & \\
Port du Scex & Rhone R. & 5220 & 180.3 & 349.5 & 12 \\
Blatten & Massa R. & 192 & 2.8 & 7.6 & 57 \\
\hline
\end{tabular}

Table 2: Input data used to drive SWIM and to calibrate/validate the model. Topography and glaciers are shown in Fig. Figure 3 Climate variables are: temperature $\mathrm{T}$ (mean, min., max.), precipitation $\mathrm{P}$, radiation and relative humidity.

\begin{tabular}{|c|c|c|}
\hline Variable & Upper Aksu & Upper Rhone \\
\hline Climate & $\begin{array}{l}\text { WATCH ( Weedon et al., } \\
\text { 2011) for T, radiation and } \\
\text { relative humidity; P from } \\
\text { APHRODITE (Yatagai } \\
\text { et al., 2012) }\end{array}$ & $\begin{array}{l}\text { climate reference data from } \\
\text { Oesterle et al. (2003) with } \\
\text { additional precipitation } \\
\text { observations from } \\
\text { MeteoSwiss }\end{array}$ \\
\hline Topography & $\begin{array}{l}\text { SRTM digital elevation } \\
\text { model at 90m (hole-filled) } \\
\text { (Jarvis et al., 2007) }\end{array}$ & $\begin{array}{l}\text { ASTER digital elevation } \\
\text { model at 30m (GDEMv2, } \\
\text { hole-filled) }\end{array}$ \\
\hline Land cover & $\begin{array}{l}\text { Chinese Meteorological } \\
\text { Administration for Chinese } \\
\text { part, MODIS } 500 \text { m land } \\
\text { cover (2001) (Friedl et al., } \\
\text { 2002) for Kyrghyz part }\end{array}$ & $\begin{array}{l}\text { CORINE Land Cover } \\
\text { (European Environment } \\
\text { Agency, 2006) }\end{array}$ \\
\hline Glaciers & $\begin{array}{l}\text { Outlines for } 1975 \text { by } \\
\text { Pieczonka and Bolch (2015); } \\
\text { Osmonov et al. (2013) and } \\
\text { GlabTop simulated volume } \\
\text { (Duethmann et al., 2015) }\end{array}$ & $\begin{array}{l}\text { Outlines for } 1973 \text { by Paul } \\
\text { (2003) and GlabTop } \\
\text { simulated volumes by } \\
\text { Linsbauer et al. ( } 2012) \text {. }\end{array}$ \\
\hline Soil & \multicolumn{2}{|c|}{ Harmonised World Soil Database (FAO, 2011) } \\
\hline Discharge & $\begin{array}{l}\text { Xiehela station from Chinese } \\
\text { hydrological yearbooks } \\
\text { (daily 1971-1987; annual } \\
\text { 1971-2000) and Sary-Djaz } \\
\text { station from Kirghiz } \\
\text { hydrological yearbooks } \\
\text { (daily 1971-1996). }\end{array}$ & $\begin{array}{l}\text { Port du Scex and Blatten } \\
\text { from GRDC (2016) (daily } \\
1980-2010) \text {. }\end{array}$ \\
\hline
\end{tabular}


Table 3: Calibration parameters ordered by model component with typical ranges. Depending on the catchment, the parameter ranges are further constrained based on available information. Parameter ranges used for the calibration presented here are given in the results section.

\begin{tabular}{llrl}
\hline Parameter & Description & Range & Unit \\
\hline Snow and glaciers & & \\
$\delta_{s}$ & Snow Degree-Day factor & $1-5$ & $\mathrm{~mm}^{\circ} \mathrm{C}^{-1} \mathrm{~d}^{-1}$ \\
$T_{s} T_{m}$ & Snow fall and melt threshold temperatures & $0 \pm 4$ & ${ }^{\circ} \mathrm{C}$ \\
$t_{e}$ & Temperature lapse rate & $-0.45--0.80$ & ${ }^{\circ} \mathrm{C} / 100 \mathrm{~m}$ \\
$\delta_{g}$ & Ice Degree-Day factor & $5-15$ & $\mathrm{~mm}^{\circ} \mathrm{C}^{-1} \mathrm{~d}^{-1}$ \\
$b_{r}$ & Residual mass balance during initialisation & $0 \pm 300$ & $\mathrm{~mm} \mathrm{a}^{-1}$ \\
\hline Precipitation (Upper Aksu catchment only) & & \\
$c$ & Max. correction factor & $1-6$ & \\
$a$ & Max. precipitation gradient & $0.05-0.9$ & $\% \mathrm{~m}^{-1}$ \\
\hline Hydrology & & & \\
$E_{c}$ & Potential evaporation correction & $0.7-1.5$ & \\
$R_{2} R_{4}$ & Routing coefficients & $1-5$ & \\
$S_{c}$ & Saturated conductivity correction factor & $0.5-2$ & \\
\hline
\end{tabular}

Table 4: Manually adjusted parameters, their value used in this study (a or b for the Upper Aksu or Upper Rhone if applicable) and the reference or reason for the final used value. Refer to Section 2.3-Section 2.9 for more detailed descriptions as well as the Supplementary Material for sensitivity analyses.

\begin{tabular}{|c|c|c|c|}
\hline Parameter & Description & Value & Reference/reason \\
\hline$\tau_{s}$ & Global shear stress* & $10 \mathrm{kPa}$ & Cuffey and Paterson, 2010 \\
\hline$\chi$ & Ice flow rheology* & $8 \times 10^{-8} \mathrm{~m}^{-4} \mathrm{a}^{-1}$ & $\begin{array}{l}\text { adjusted to GlabTop2 simulations, } \\
\text { Linsbauer et al., } 2012\end{array}$ \\
\hline$\alpha_{a}$ & Avalanche slope threshold & a) $35^{\circ}$, b) $38^{\circ}$ & $\begin{array}{l}\text { adjusted to ice-free slopes in the } \\
\text { accumulation zones }\end{array}$ \\
\hline$\Gamma$ & Sublimation energy ratio & a) $25 \%$, b) $20 \%$ & Luo et al., 2013; Kaser, 2001 \\
\hline$\gamma$ & Subdebris melting slope factor & 0.0572 & Hagg et al., 2008 \\
\hline$C_{0}$ & Initial debris concentration* & $0.12 \%$ & $\begin{array}{l}\text { Bozhinskiy et al., } 1986 \text {, sensitivity } \\
\text { tests at large glacier termini }\end{array}$ \\
\hline$t_{r}$ & Melt water residence time & a) 2.8 , b) 1.9 & $\begin{array}{l}\text { adjusted to precipitation-free melt } \\
\text { event }\end{array}$ \\
\hline
\end{tabular}

a) Upper Aksu, b) Upper Rhone

*Sensitivity analysis provided in the Supplementary Material (Section S2). 
Table 5: Calibrated parameters (min., median, max.) for both investigated catchments over the best 25 parameter sets. Refer to Table 3 for a description and upper and lower bounds of the parameters.

\begin{tabular}{|c|c|c|c|c|c|c|c|}
\hline \multicolumn{2}{|c|}{ Parameter } & \multicolumn{3}{|c|}{ Upper Aksu } & \multicolumn{3}{|c|}{ Upper Rhone } \\
\hline & & $\min$ & median & $\max$ & $\min$ & median & $\max$ \\
\hline$\delta_{s}$ & Snow Degree-Day factor & 3.2 & 3.8 & 4.1 & 2.7 & 4.0 & 5.0 \\
\hline$T_{s}$ & Snow fall threshold & 2.2 & 3.3 & 3.8 & -2.3 & 1.3 & 1.9 \\
\hline$T_{m}$ & Snow melt threshold & -2.0 & -1.2 & -0.7 & -1.2 & -0.5 & 1.6 \\
\hline$t_{e}$ & Temperature lapse rate & 0.78 & 0.72 & 0.68 & 0.60 & 0.56 & 0.49 \\
\hline$\delta_{g}$ & Ice Degree-Day factor & 5.8 & 8.6 & 11.6 & 6.1 & 8.8 & 10.3 \\
\hline$b_{r}$ & Residual mass balance & -281 & -250 & -182 & -129 & -79 & 149 \\
\hline$c$ & Max. P correction factor* & 3.1 & 3.6 & 3.9 & & & \\
\hline$a$ & Max. P gradient* & 0.31 & 0.34 & 0.37 & & & \\
\hline$E_{c}$ & Potential evap. correction & 0.61 & 0.79 & 1.15 & 0.74 & 1.08 & 1.41 \\
\hline$R_{2}$ & Routing coefficients & 0.5 & 1.1 & 3.1 & 1.3 & 3.8 & 5.0 \\
\hline$R_{4}$ & & 0.9 & 2.7 & 4.1 & 1.6 & 4.6 & 5.0 \\
\hline$S_{c}$ & Sat. conductivity correction & 0.6 & 1.2 & 1.9 & 1.0 & 1.3 & 1.7 \\
\hline
\end{tabular}

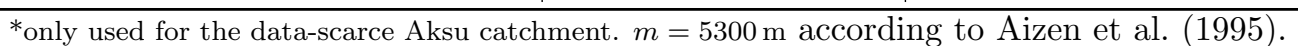

Table 6: Model performance for all four objectives: median (min., max.). The Nash-Sutcliffe Efficiency NSE and the bias in the water balance PB are given for the calibration and validation period (split-sample approach). The absolute and relative error of the glacier area hypsometry $\mathbf{A}$ is given as a fraction of total glacier area. The simulated annual mass balances $\mathbf{M B}$ are compared to observed values by Pieczonka and Bolch (2015) (Upper Aksu) and Fischer et al. (2015) (Upper Rhone).

\begin{tabular}{|c|c|c|c|c|}
\hline Station & $\begin{array}{l}\text { NSE } \\
\text { calibration } \\
\text { validation }\end{array}$ & $\begin{array}{l}\mathbf{P B}[\%] \\
\text { calibration } \\
\text { validation }\end{array}$ & $\begin{array}{c}\mathbf{A}[\%] \\
\text { abs. residuals } \\
\text { rel. total }\end{array}$ & $\begin{array}{c}\text { MB }\left[\mathrm{m}_{\mathrm{w}} . \mathrm{e} . \mathrm{a}^{-1}\right] \\
\text { simulated } \\
\text { observed }\end{array}$ \\
\hline \multicolumn{5}{|c|}{ Upper Aksu } \\
\hline Xiehela & $\begin{array}{l}0.82(0.81,0.83) \\
0.84(0.82,0.85)\end{array}$ & $\begin{array}{c}0.8(-4.4,2.3) \\
-2.4(-7.7,-1.1)\end{array}$ & $\begin{array}{l}16.3(14.2,19.5) \\
-1.1(-11.5,2.4)\end{array}$ & $\begin{array}{l}-0.36(-0.37,-0.34) \\
-0.35 \pm 0.34\end{array}$ \\
\hline Sary-D. & $\begin{array}{l}0.63(0.60,0.70) \\
0.66(0.61,0.72)\end{array}$ & $\begin{array}{r}0.8(-2.6,5.3) \\
-7.9(-11,-3.7)\end{array}$ & $\begin{array}{l}25.9(18.7,31.2) \\
11.3(-5.3,18.5)\end{array}$ & $\begin{array}{l}-0.33(-0.37,-0.33) \\
-0.35 \pm 0.34\end{array}$ \\
\hline \multicolumn{5}{|c|}{ Upper Rhone } \\
\hline Port d. S. & $\begin{array}{l}0.67(0.66,0.68) \\
0.62(0.60,0.64)\end{array}$ & $\begin{array}{c}-1.8(-2.8,-1.4) \\
0.8(-0.3,1.4)\end{array}$ & $\begin{array}{l}12.6(10.8,15.8) \\
-8.8(-13.8,6.8)\end{array}$ & $\begin{array}{l}-0.67(-0.72,-0.58) \\
-0.59 \pm 0.07\end{array}$ \\
\hline Blatten & $\begin{array}{l}0.89(0.86,0.90) \\
0.89(0.85,0.90)\end{array}$ & $\begin{array}{l}-0.1(-1.0,1.0) \\
-2.7(-4.7,0.6)\end{array}$ & $\begin{array}{l}8.4(7.2,10.0) \\
-1.0(-6.7,2.1)\end{array}$ & $\begin{array}{l}-0.87(-0.96,-0.80) \\
-0.80 \pm 0.07\end{array}$ \\
\hline
\end{tabular}




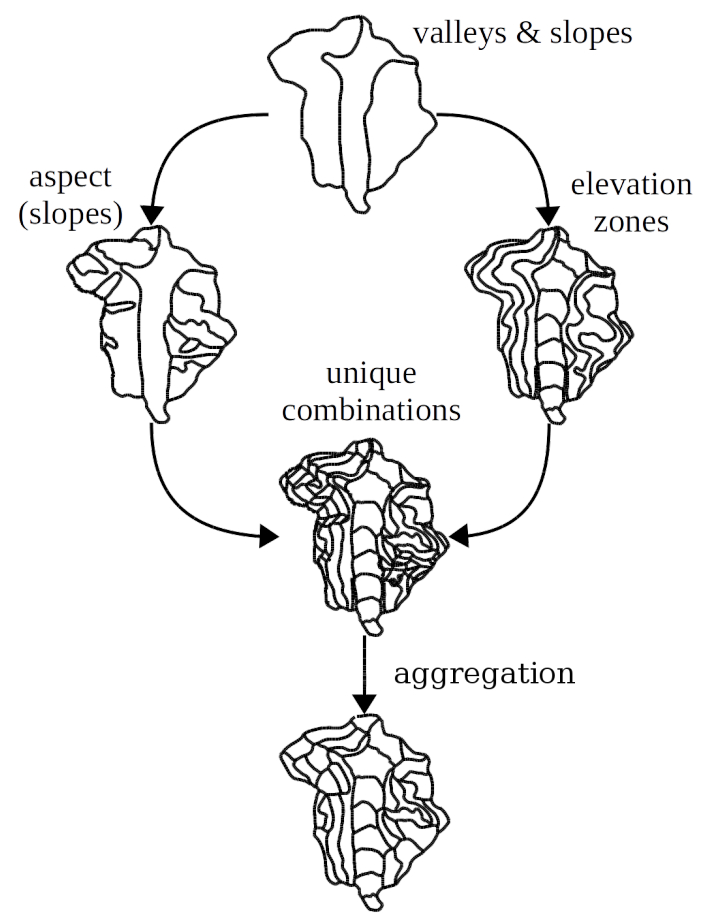

Figure 1: Spatial disaggregation within a subbasin as the representative glacier units.

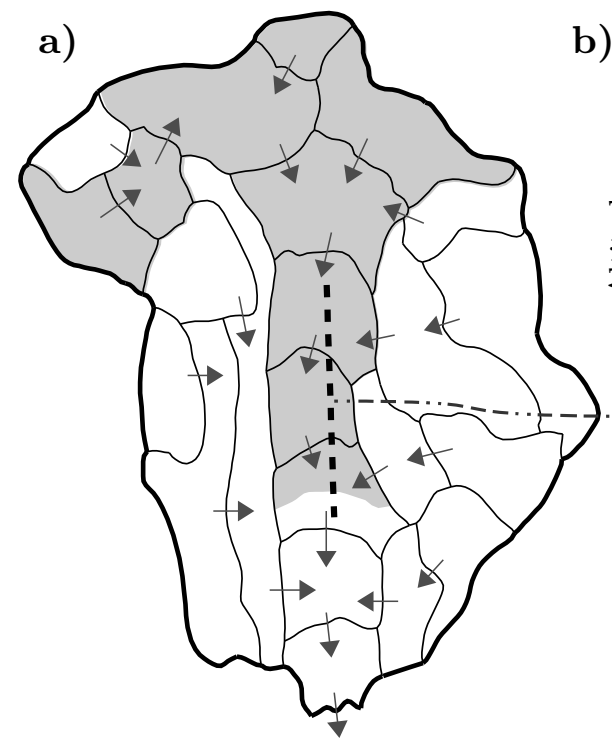

b)

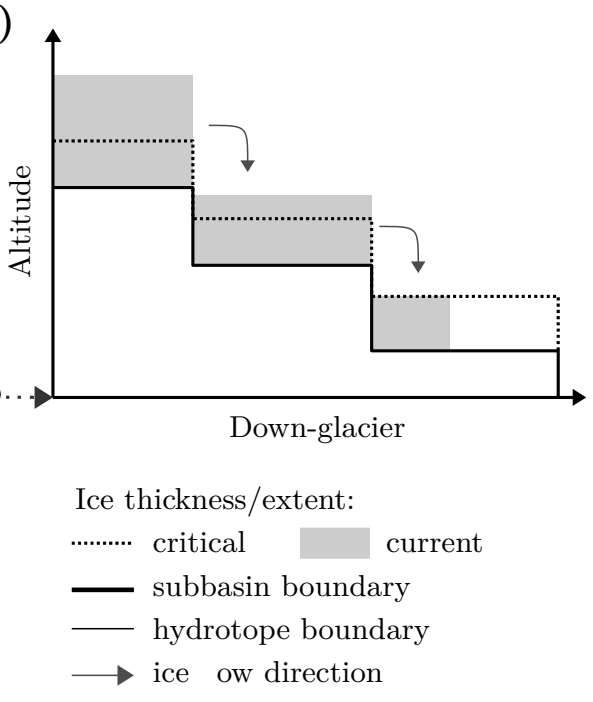

Figure 2: Schematic representation of ice routing in a single subbasin (a) and through a valley cross-section of three glacier units (b). 


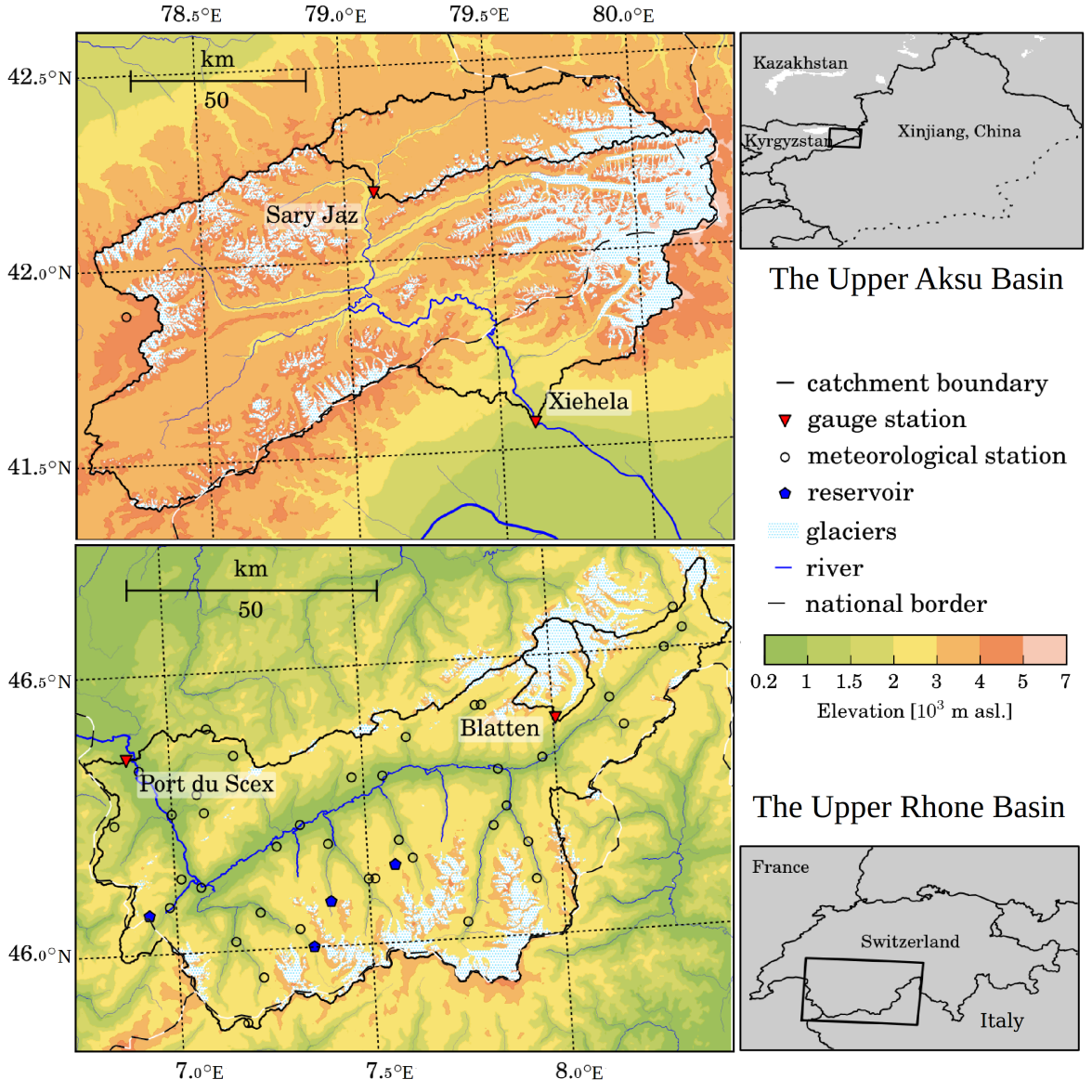

Figure 3: Overview maps of the two case study basins. Glacier cover is only shown inside the catchments. 

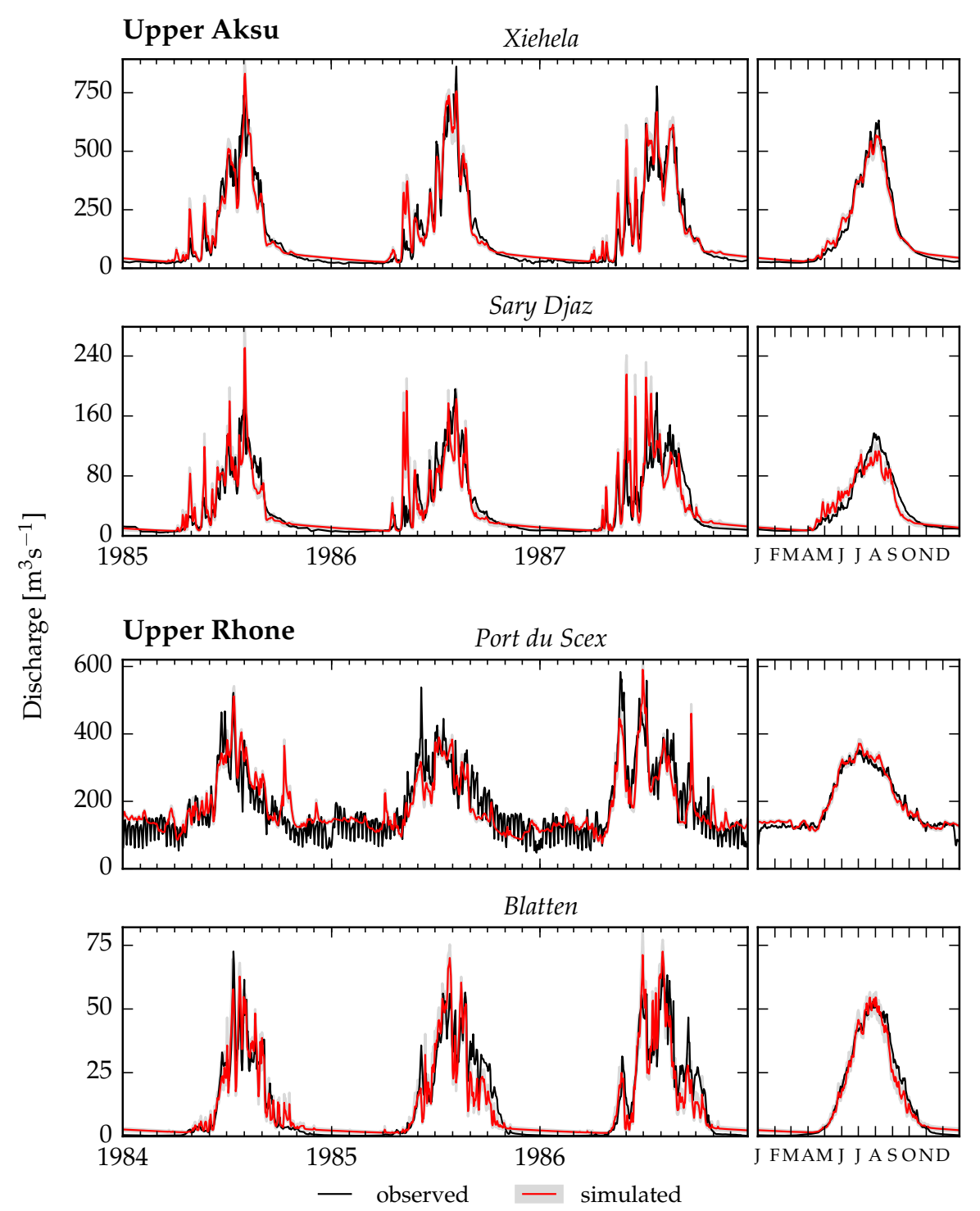

Figure 4: Calibrated discharge for the outlet stations (Xiehela and Port du Scex) and intermediate stations (Sarj Djaz and Blatten) of both catchments. Daily discharge (left) is shown for a selected period while day of year mean discharge (right) is taken over the entire calibration and validation period. The oscillations in the Port du Scex discharge are the effects of weekend dam closures. 


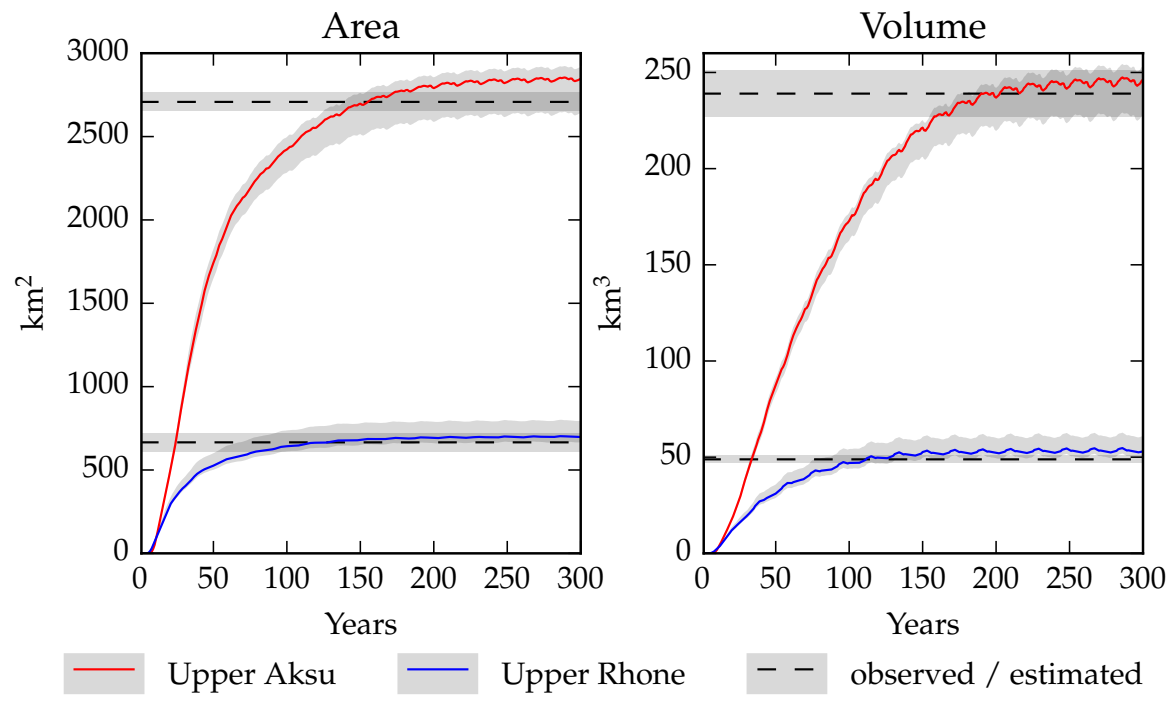

Figure 5: Development of area and volume over the 300-year initialisation period in the Upper Rhone and the much larger Upper Aksu catchment. Observed area ranges are taken from Paul (2003) and Pieczonka and Bolch (2015); Osmonov et al. (2013). Volume estimations are based on modelled glacier thicknesses in the Upper Aksu catchment and in the Upper Rhone catchment by Linsbauer et al. (2012). 


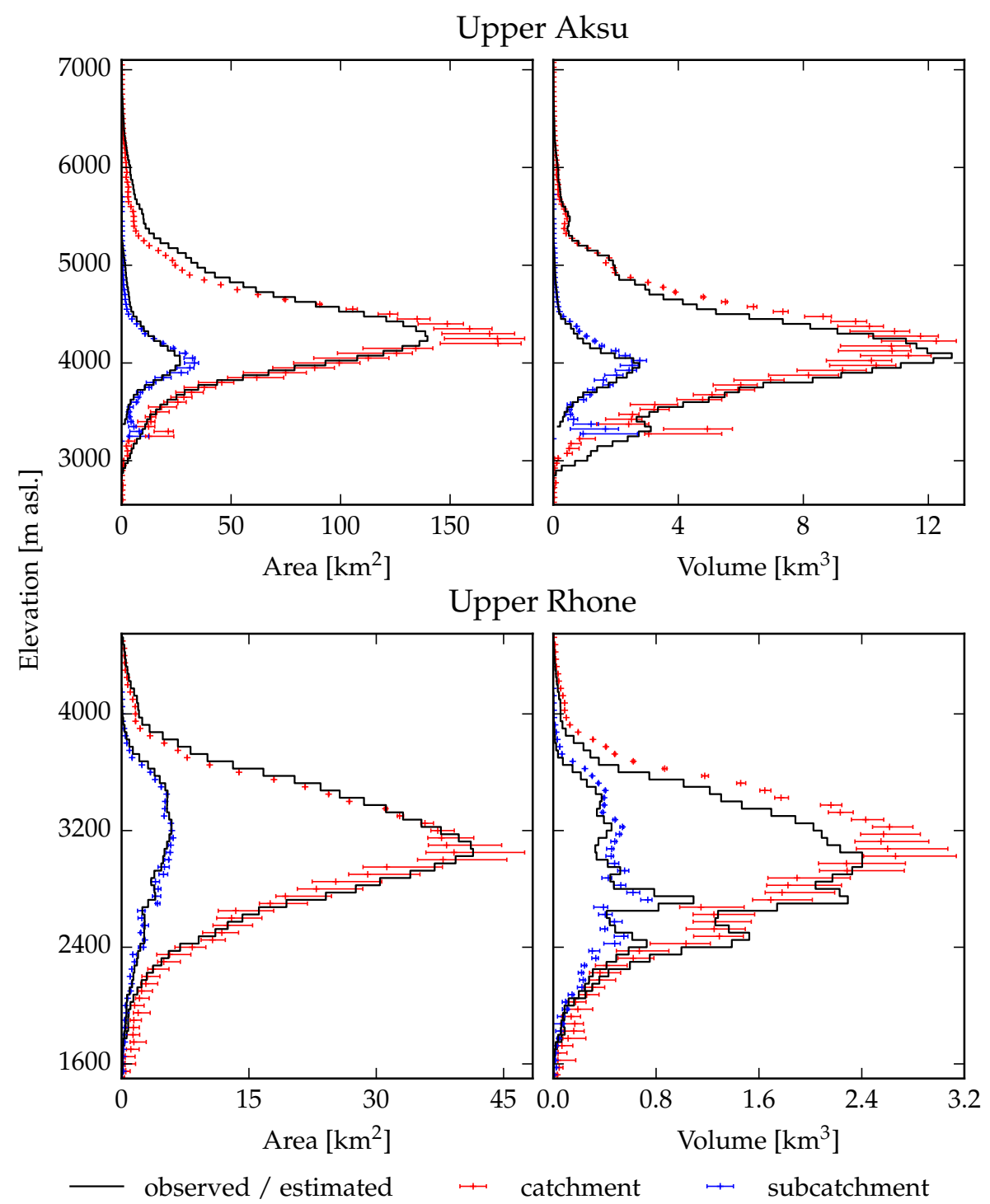

Figure 6: Initialised glacier area and volume hypsometry (i.e. distribution over 50m elevation zones). The catchment-wide hypsometry is shown with the subcatchments of the Sary-Djaz gauging station in the Upper Aksu catchment and the Blatten station in the Rhone catchment, which encompasses the Great Aletsch Glacier. Observed areas are taken from Pieczonka and Bolch (2015) in the Upper Aksu catchment and from Paul (2003). Volume estimations are based on modelled glacier thicknesses in the Upper Aksu catchment by Pieczonka and Bolch (2015) and in the Upper Rhone catchment by Linsbauer et al. (2012). 

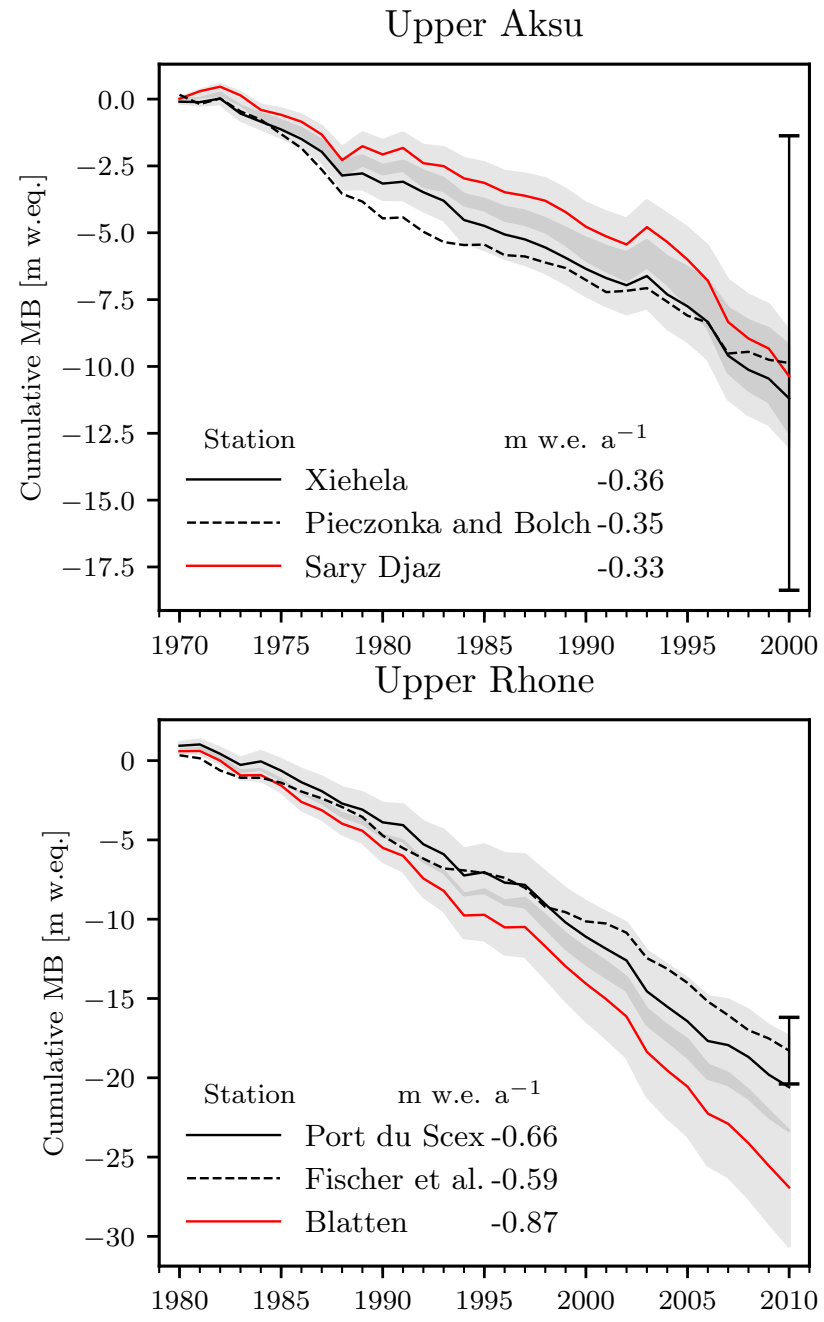

Figure 7: Median of simulated mass changes including ranges induced by the parameter uncertainty. The dashed black line shows the reference glacier mass balance scaled by the catchment-wide geodetic mass balance from the indicated studies including uncertainty bars from those studies. Note that the scaled/observed mass balance and the uncertainty bar (black) only refers to the entire catchment, i.e. the outlet station. Annual mean values over the simulation period are indicated in the legend. 

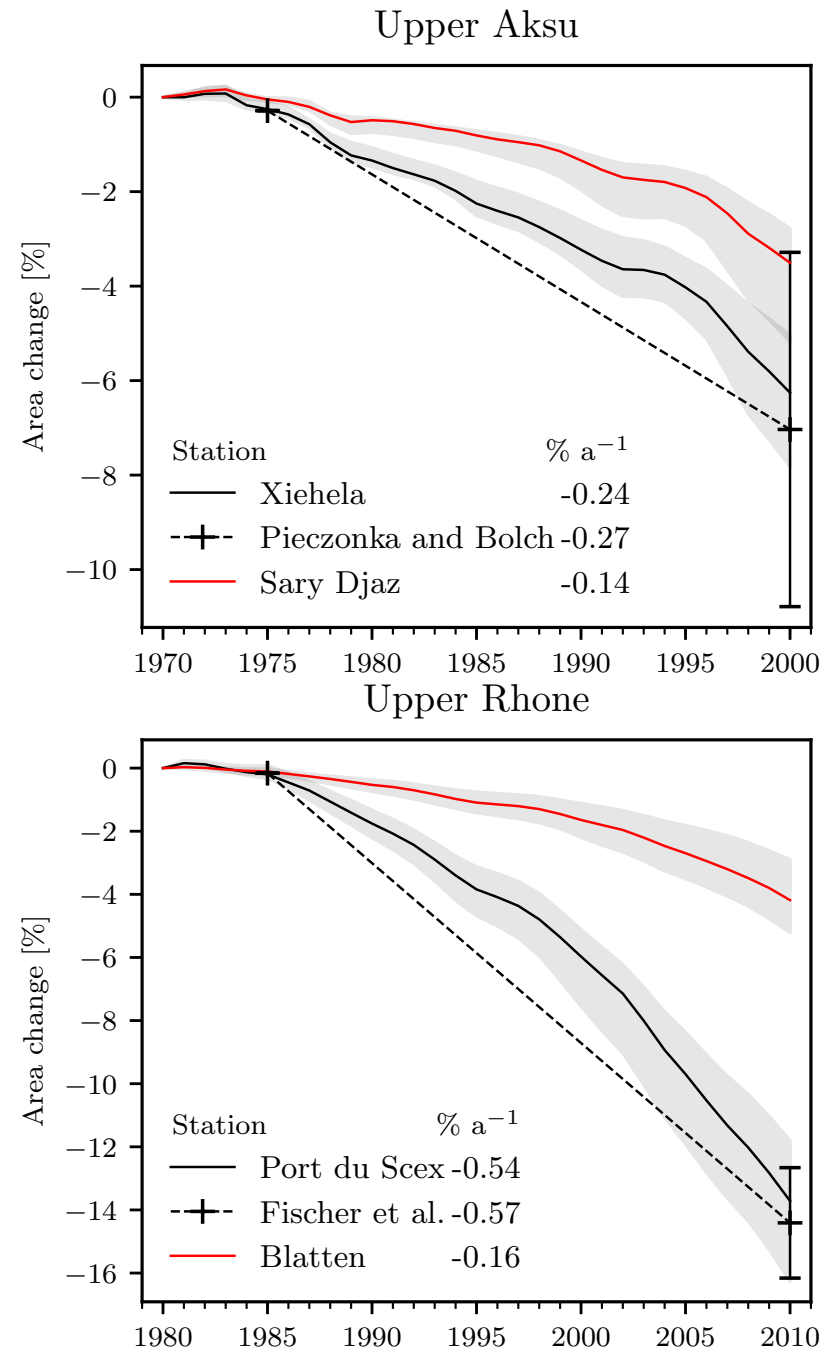

Figure 8: Median of simulated relative glacier area changes including ranges induced by the parameter uncertainty. The observed geodetic area changes from the indicated studies are shown by the dashed line with uncertainty ranges. Mean values over the simulation period are indicated in the legend. 


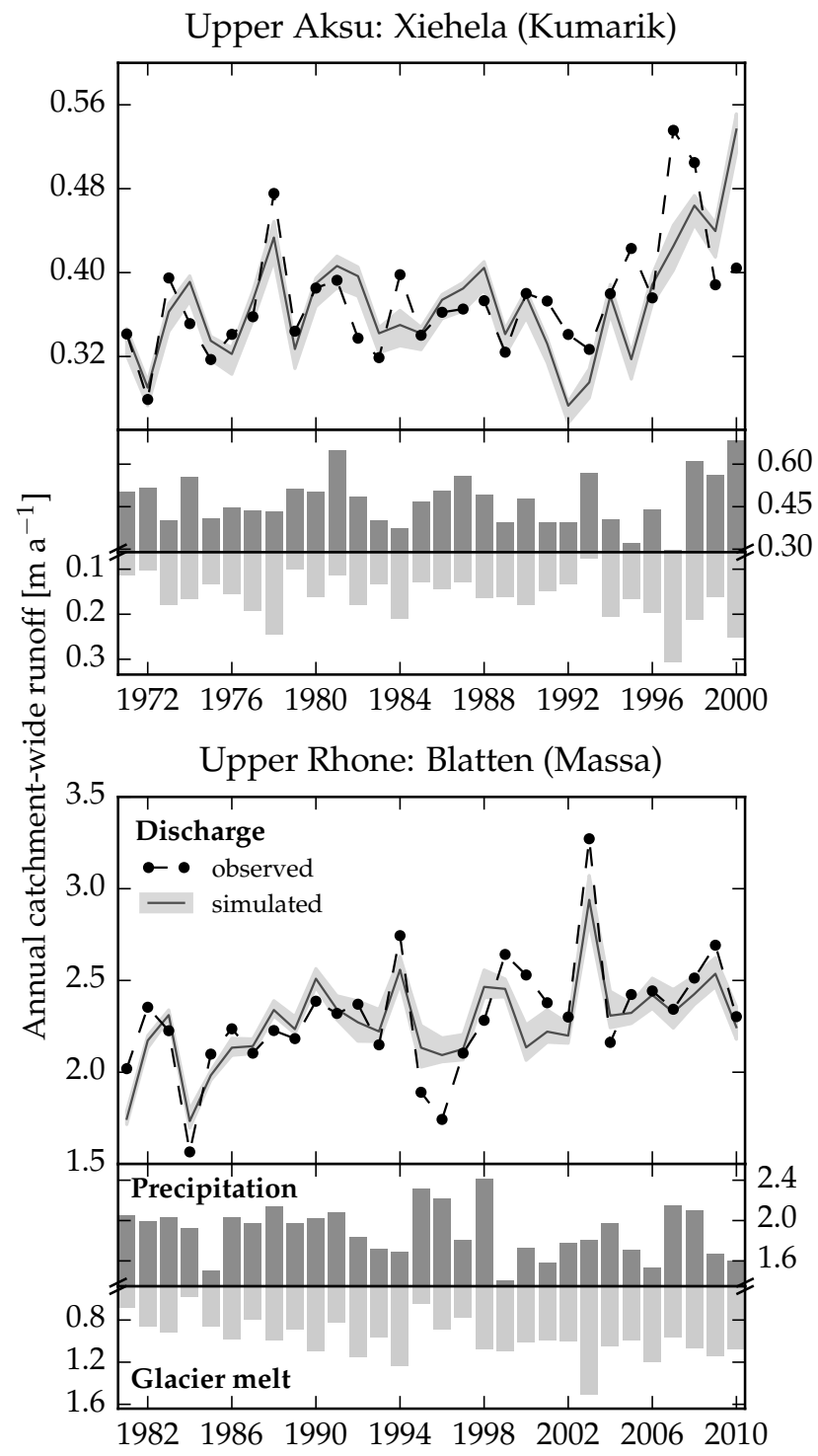

Figure 9: Simulated (median, min., max.) and observed mean annual discharge at Xiehela (Kumarik) and Blatter (Massa) stations with annual precipitation and glacier melt distributed over the catchment area. 